\title{
RUSSIA \& LEGAL HARMONIZATION: AN HISTORICAL INQUIRY INTO IP REFORM AS GLOBAL CONVERGENCE AND RESISTANCE
}

\author{
BORIS N. MAMLYUK*
}

\begin{abstract}
This Article examines several waves of intellectual property (IP) regulation reform in Russia, starting with an examination into early Soviet attempts to regulate intellectual property. Historical analysis is useful to illustrate areas of theoretical convergence, divergence, and tension between state ideology, positive law, and "law in action." The relevance of these tensions for post-Soviet legal reform may appear tenuous. However, insofar as IP enforcement has emerged as one of the largest hurdles for Russia's prolonged accession to the World Trade Organization (WTO), these historical precedents may help explain Russia's apparent theoretical and political disconnect from the WTO. If Russian policymakers and many Western analysts agree that Russia has complied with all necessary structural adjustment reforms for WTO accession (including reforming its IP legislation), then deeper points of contention between Russia and the West must be identified. One point of departure, the Article posits, is Russia's lingering inability to convey adherence to general international law.

Thus, this Article re-conceptualizes the link between domestic and international legal orders by connecting the IP debate to broader debates over the nature of international law in the Soviet and post-Soviet space. Specifically, Part I examines how Soviet theorists attempted to reconcile IP regulation with Marxist ideology and socialist international law. Part II surveys the main IP law reform projects in post-Soviet Russia from 1992

* Assistant Professor of Law, University of Memphis, Cecil C. Humphreys School of Law; Visiting Assistant Professor, Ohio Northern University, Claude W. Pettit College of Law (2010-2011); Visiting Scholar, Cornell Law School (2009-2010); Ph.D. in Law, Economics \& Institutions (2011), CLEI Centre, University of Torino, Faculty of Law; Fulbright Fellow, Institute of State and Law, Russian Academy of Sciences (2008-2009); J.D. (2005), University of California (Hastings). I would like to thank the organizers and participants of the January 2010 Toronto Group conference and the January 2010 LSE/SOAS international law colloquium for their insightful comments and criticism on related presentations. In addition, I would like to thank Gianmaria Ajani, Michele Graziadei, Mitch Lasser, Chantal Thomas, Antony Anghie, John D. Haskell, Golnoosh Hakimdavar, John Barcelo, Ugo Mattei, Nikolay Mamluke, and the participants of the Cornell Graduate Research Colloquium for their support and valuable friendship.
\end{abstract}


to 2006, with particular emphasis on harmonization with global legal standards. The second part also provides a brief comparative analysis of Russia's latest IP law (effective 2008) and copyright protections in U.S. law as well as the 1971 Berne Convention. The Article concludes with an overview of doctrinal debates within Russia over harmonization, WTO accession, and international law. These debates shed light on the development of local resistance to further legal harmonization efforts, an issue of immediate relevance not just for policymakers working with Russia, but for broader law and development debates.

\section{TABLE OF CONTENTS}

INTRODUCTION 536

I. EARLy SOVIET IP PROTECTION: THEORY AND PRACTICE ................... 538

A. Why Turn So Far to History? ............................................ 538

B. Lenin as IP Regulator-in-Chief? ...................................... 538

1. The Dilemma of Attracting Foreign Trade

(Pragmatism \& International Law) ............................ 544

2. The Dilemma of Reconciling Communism, NEP \& IP... 557

C. Late Soviet IP Protection: An Overview ................................. 563

II. RUSSIAN IP LAW (1992-2006): TRANSITION ................................. 566

A. Change, Transplants, and Harmonization .......................... 566

B. Policy-Driven Harmonization (2000-Present) .................... 571

1. WTO, TRIPS \& the American Lobby........................... 572

2. Russian Civil Code (Part IV) and Legal Licenses.......... 576

3. Russian Legal Licenses v. U.S. "Fair Use" \& Berne

Convention..................................................................... 579

C. Policy Trade-Offs, Resistance, Values, and Interests............. 587

\section{INTRODUCTION}

Twenty years after the fall of the Berlin Wall, has Russia finally ended its transition and completed its restoration/reintegration into the international legal order? If so, has Russia developed a novel theory of international law or has it fully subscribed to the liberal international legal model? In his 2003 introduction to the second edition of G.I. Tunkin's Theory of International Law, William E. Butler, the eminent legal scholar of Soviet/Russian law, noted that ' $[\mathbf{t}]$ here is no 'substitute' or 'replacement' theory, as yet, to supersede the insights into international 
behaviour identified by Academician G.I. Tunkin." Taking as granted that Russia has not fully adopted a liberal theory of state and law along Western lines, as most observers had hoped, it is worthwhile to reexamine the countless continuities and discontinuities between the Soviet and postSoviet Russian experience with international law and institutions. Considering Russia's increasingly aggressive foreign policy posture and growing uncertainty over the viability of domestic reforms, ${ }^{2}$ it is vitally important to take stock of these difficult - and largely unquantifiableaspects of Russian reforms, from the enduring legacy of great power/socialist/bureaucratic thinking still prevalent among Russia's policy and academic elites, to more concrete issues like Russia's attempt to project respect for property rights to potential investors.

The present Article explores these historical breaks and continuities in the context of Russia's intellectual property reforms. ${ }^{3}$ The analysis follows two parts. Part I offers a brief legal history of Soviet regulation of intellectual property ("IP") rights, starting in the early 1920 s when the Soviet state was first engineering its socialist legal system in an apparent attempt to break away from the global "bourgeois" legal order. The first Part also provides an overview of the "mature" or classic Soviet IP regime. Part II presents a synopsis of IP law reform projects in post-Soviet Russia and Russia's attempts to harmonize its IP legislation with international norms throughout the 1990s. Part II also compares Russia's subsequent IP law reforms to U.S. copyright law, particularly in reference to legal licenses or "fair use," through a traditional functionalist comparative law methodology. ${ }^{4}$ The Article concludes with a broader discussion on the effectiveness of Russia's attempts to harmonize its domestic IP system with international norms, including a study of resistance. This in turn allows an evaluation of alternative policy options or alternative normative

1. William E. Butler, Introduction to G.I. TUNKIN, THEORY OF INTERNATIONAL LAW xiii (William E. Butler trans., 2d ed. 2003).

2. See Dmitri Trenin, Russia Reborn: Reimagining Moscow's Foreign Policy, ForeIGN AfFAIRS, Nov.-Dec. 2009, at 64; see also Boris N. Mamlyuk, Book Review, 35 REV. CENT. \& E. EUR. L. 111 (2010) (reviewing INTERNATIONAL LAW-A RUSSIAN INTRODUCTION (Valerti I. Kuznetsov, Bakhtiar R. Tuzmukhamedov eds., 2009)).

3. This Article is Chapter 6 of a larger dissertation on the development of international legal theory in Russia during two moments of crisis, the Interwar period (1919-1939) and the post-Soviet period (1989-2009).

4. Michele Graziadei, The Functionalist Heritage, in COMPARATIVE LEgal STUdies: TRADitions AND TRANSiTions 104-08 (Pierre Legrand \& Roderick Munday eds., 2003); Mary Ann Glendon, Michael W. Gordon \& Christopher Osakwe, Comparative Legal Traditions 11-12 (2d ed. West 1994). On functionalism more broadly, see the classic Robert K. Merton, SOCIAL THEORY AND SOCIAL STRUCTURE 73 (1968 Enlarged Edition) 
approaches to law reform and law and development projects not just in Russia, but in other transitioning states.

\section{EARLY SOVIET IP PROTECTION: THEORY AND PRACTICE}

\section{A. Why Turn So Far to History?}

Most historical studies looking at IP reform in post-Soviet Russia start with the classic or late Soviet period (1960-1989) as a point of departure. ${ }^{5}$ This is a useful starting place. However, the early Soviet period-the interwar years of 1919-1939-offers a remarkably sophisticated complementary analytical frame for considering the inner tensions and incongruities of Soviet legal theory and practice. How the Soviet Union came to recognize IP rights despite openly professing to oppose "private property" (and any laws that upheld the right of ownership to the means of production) may shed further light on the ambiguous intellectual structures of Soviet law, and by legacy, the post-Soviet legal system.

\section{B. Lenin as IP Regulator-in-Chief?}

A core tenet of Marxism and Leninism was the abolition of private property over the means of production and a critique of property forms generally. ${ }^{6}$ As such, it may come as a surprise that the early Soviet state protected IP rights. Yet the early Soviet state was an ardent defender of individual and commercial right holders' claims both foreign and domestic, and not merely under the New Economic Policy which briefly liberalized the Soviet economy from 1922 to 1929 . Lenin himself issued no less than a half dozen decrees on copyright and authors' rights protections between 1917 and 1922. What explains this apparent paradox? Did not the very notion of owning an idea or a work of art contradict the socialist conception of mass production and commonality of title? The

5. See, e.g., William E. Butler, Intellectual Property LaW in the Russian Federation xv (4th revised ed. 2005). The notable exception in this regard is Michiel Elst's comprehensive historical study. See Michiel Elst, COPYRight, FreEdom of SPEECh, ANd Cultural Policy IN the Russian FEDERATION (Martinus Nijhoff 2005); see also SERGE L. LeVITSKY, Copyright, Defamation, and Privacy in Soviet Civil LaW: De Lege Lata AC Ferenda (1979). Elst and Levitsky, however, do not connect the history of IP regulation in the USSR and post-Soviet Russia with broader debates in Soviet/pre-Soviet international legal theory and practice, which is the goal of the present analysis.

6. See generally Rudolf SCHLESInger, SOVIEt Legal THEORy (1945); EVGEny PASHUKANiS, LAW AND MARXISM: A GENERAL THEORY (Barbara Einhorn trans., Inklinks 1978); HANS KELSEN, THE COMMunist THEORY OF LAW ch. 5 (1955); Hugh W. BABB, SOVIET LeGal PHILOSOPHy (1951); WILLIAM E. BUTLER, RUSSIAN LEGAL THEORY (1996). 
answer to this question goes to the heart of the early Soviet theory of state and law and invokes fundamental theoretical debates that rocked the Soviet legal establishment throughout the interwar period. A quick survey of these debates is useful to contextualize the discussion that follows.

One reason for the eruption of fierce debates regarding the nature and function of law following the Bolshevik Revolution was that Marx did not expressly formulate the contours of post-revolutionary law and the state. ${ }^{7}$ Had Marx theorized law as he had intended, it is likely that the Bolsheviks' piety to his teachings would have reduced the ensuing legal drama to a well-managed bureaucratic transition. ${ }^{8}$ Absent that, it was left to the Bolsheviks to navigate the problems of managing a failed state through a series of foreign and domestic challenges while attempting to create consistent theoretical justification for their actions.

The most influential application of Marxist theory to the problem of political reorganization following the proletarian revolution was by Lenin himself in his State and Revolution. ${ }^{9}$ Here, Lenin restated the main theses of Marx and Engels on the state, including the theory of class rule, formulated the theory of a Marxist state ruled by the proletarian class, and defended his conception against "opportunists," including the German Social-Democrats and English Fabians from the Second International. Lenin outlined the class nature of governments, the origins and role of the state, and bourgeois' use of class antagonism in maintaining the state. ${ }^{10} \mathrm{He}$ further critiqued what he described as a petit-bourgeois illusion of gradual transformation of capitalism into socialism without revolution.

7. Marx touches upon issues of law and economic relations as a basis for law in his Critique of the Gotha Program. See Karl MarX, Critique of THe Gotha Program (Int'1 Publ. Co., Inc. 1938) (1875). But he does not offer a theory of law, or a programmatic analysis of the role of law in a communist society.

8. В.В. ЛАПАЕВА, ВОПРОСЫ ПРАВА В КАПИТАЛЕ МАРКСА 5-6 (Юр. ЛиТ., 1982) [VALENTINA ViKTORONA LAPAEVA, QUestions of LAW IN MARX's CAPITAL, 5-6 (Jur. Lit. 1982)]. Lapaeva's succinct explanation of the doctrinal disagreements between eminent theorists P.I. Stuchka and E.B. Pashukanis, on the one hand, and I. Razumovsky, on the other, provides an excellent summary of the debates and is a good starting point for scholars interested in understanding the official post-Stalin position on Pashukanis. According to Lapaeva, Razumovsky was able to demonstrate, unlike Pashukanis, that abstract and concrete conceptions of the legal form did not necessarily require the abolition of law, since law did not encompass all relations between property owners, but rather represented only one aspect of economic relations. $I d$. at 7-9.

9. See ЛЕНИН, ГОСУДАРСТВО И РЕВОЛЮЦИЯ: УчЕНИЕ МАРКСИЗМА О ГОСУДАРСТВЕ И ЗАДАЧИ ПРОЛЕТАРИАТА В РЕВОЛЮЦИИ (1917) (Полное собрание соч., 5 изд. т 33 с. 1-120) [Vladimir ILYTCH LENIN, State ANd ReVOlution (Robert Service trans., Penguin 1992)].

10. Lenin theorized that despite differences in form between modern bourgeois states (parliamentary, traditional monarchic), the dictatorship of the capital owning class (the bourgeois class) over the proletarian united these diverse forms. 
According to Lenin, following a socialist revolution, the dictatorship of the proletariat would develop into a strong, centralized democratic base of Soviets (or workers' councils). The central communist party would play a guiding role in the construction of this socialist state by ensuring discipline, organization, and redistribution of material resources. Most importantly, Lenin developed and theorized Marx/Engel's writings on the dual phases of communism, the immediate socialist state following a socialist revolution, and a higher phase of communism which would finally see the withering away of the state. Contrary to Bukharin, ${ }^{11}$ Lenin claimed that the transition to communism could only come after strengthening the state administrative organs and consolidating power in the hands of the Soviets and the party. Furthermore, this consolidation of power would coincide with the development of other proletarian movements across the world. Thus, Lenin theorized the importance and, indeed, inevitability of the transition period as a political and strategic necessity, but also as a forceful rhetorical and argumentative tool. As we shall see, this formulation would serve as the basis for Korovin's transition theory of international law and all subsequent Soviet theories of international law until the development of the doctrine of permanent peaceful coexistence in 1963. This transition theory would also have a direct impact on the development of private law in the early Soviet state.

Per Lenin, until the "highest form of communism" arose, the party would need to exercise strict control over society and the state to regulate labor, production, and consumption. ${ }^{12}$ This highest form of communism would occur when society would overcome the differences between physical and mental labor, divisions of standards of living between urban and rural workers, and as a result of the mixing of nations (ethnicities). ${ }^{13}$ In State and Revolution, Lenin did not specify the role of law in the transition from bourgeois order to socialism; indeed law is mentioned but once in a discussion of the Anti-Socialist Law in Germany. ${ }^{14}$ However, in The Proletarian Revolution in Russia, a collection of articles and speeches by Lenin and Trotsky, it was clear that legal control was meant to be

11. Н. Бухарин, К теории империалистического государства, РЕВОЛЮЦИЯ ПРАВА 5 (Нзд. Ком. Акад., 1925) [Nikolai Bukharin, Towards a Theory of the Imperialist State, in REVOLUTSIA PRAva 5 (Communist Acad. 1925)]. To Bukharin, the post-revolutionary state existed only in a transitory moment and could not be strengthened after the revolution. The state apparatus had to be reduced in direct correlation with the elimination of classes. Id. at 13 . This directly contradicted Lenin's position on the need to strengthen the communist apparatus.

12. LENIN, supra note 9, at 97.

13. Id. at 93-97.

14. Id. 
exercised directly by the Soviets through direct democracy. ${ }^{15}$ But immediately a theoretical crisis presented itself.

According to Marx, the state and the law are elements of a social superstructure determined by the economic relations and activities (the base) of the ruling classes of a particular society. If the purpose of the Soviet state was to destroy this superstructure and replace it with a domestic communist order, then law should have had no function in the new Soviet state. In other words, because law was the manifestation of class struggle and reinforced class difference, the abolition of class would require the simultaneous abolition of law. This thesis was famously theorized by the early Soviet legal philosopher Evgeny Pashukanis (18911937 ) in his 1924 General Theory of Law and Marxism. ${ }^{16}$ Pashukanis went even further than merely exposing the logical inconsistency of maintaining law in a classless society. He argued that since law arose as a consequence of property exchange, it was necessary to eliminate law in an effort to disrupt the cycle of property rights, commodity fetishism, and material relations between individuals in the new Soviet state. ${ }^{17}$ In short, law went hand in hand with property and vice versa. Only by abolishing both law and property could individuals rise to a higher form of social consciousness and political awareness. ${ }^{18}$

Analogously, on the international plane, it was theoretically impossible for the Soviet Union to exist in a world system of law which was built by the bourgeois and imperialist ruling class, comprised of the powerful imperial nations that reached their zenith in the nineteenth century. ${ }^{19}$ These differences between socialism and capitalism were deemed a priori to be irreconcilable by some jurists (like Stuchka and Pashukanis). ${ }^{20}$ Other early Soviet jurists, like A.G. Goikhbarg, however, saw the potential of reinventing law to serve the interest of the proletarian class through the creation of the Bolshevik law that would administer the dictatorship of the

15. Vladimir Lenin \& Leon Trotsky, The Proletarian Revolution in Russia 83 (1918).

16. PASHUKANIS, supra note 6.

17. Id. at $109-33$.

18. Id.

19. Id. at 6 (arguing that a subject under international law is identical to a subject under municipal law).

20. Id. at 52 (“Современное международное право включает в себя весьма солидную дозу самоуправства (реторсии, репрессалии, войны и т. д.)" [“Contemporary international law includes a solid dose of contradictory 'self-regulation' (retribution, repression, war, etc.)."]). Id. at $67 \mathrm{n} .148$ (“[...] в международных отношениях государство выступает вовсе не как воплощение объективной нормы, но как носитель субъективных прав, т. е. со всеми атрибутами субстанциональности и эгоистической заинтересованности." [“[ . . ] in international relations, the state does not act as embodying objective norms, but acts as a holder of subjective rights, that is with all of the attributes of substantive and egoistic self-interestedness."]). 
proletariat. ${ }^{21}$ In international law, this meant the creation of a Bolshevik legal order or a socialist international law governing relations between Socialist-dominant states and capitalist states. ${ }^{22}$

Although he was an attorney who often spoke and wrote on such central topics as self-determination, sovereignty, non-intervention, and international economic law, Lenin did not participate in these core theoretical debates. ${ }^{23}$ This occurred for at least three reasons. First, as the chief executive of the Soviet state, Lenin was too preoccupied with more urgent matters of war and peace. During the first two months of Soviet Russia's existence, for instance, Lenin issued more than forty decrees concerning foreign relations. ${ }^{24}$ In the first five years (1917-1922), more than 270 legal acts were adopted concerning foreign relations. ${ }^{25}$ Second, it is well-known that Lenin preferred to write in populist form to emphasize the relevance of his theories to the working masses. ${ }^{26}$ Therefore, it is not surprising that he avoided the theoretical fights on the pages of Soviet law

21. A.G. Goikhbarg was the first Director of the Institute of Soviet Law from 1922 to 1925 . After Pashukanis gained control over the Soviet legal academy in 1932, he expelled Goikhbarg from his teaching post for maintaining "bourgeois" attachment to the notion of Soviet law. Goikhbarg was ultimately jailed, but rehabilitated after WWII.

22. ЕВГЕНИЙ А. КОРОВИН, МЕЖДУНАРОДНОЕ ПРАВО ПЕРЕХОДНОГО ВРЕМЕНИ (М., 1924) [Evgeny A. Korovin, International Law of the Transition Period (1924)].

23. In fact, his writings on international law were ultimately collected and published as a standalone volume by the Soviet Institute of International Relations. ЛЕНИН О МЕЖДУНАРОДНОЙ ПОЛИТИКЕ И МЕЖДУНАРОДНОМ ПРАВЕ (ИЗД-вО ИН-Та МЕЖДУНарОДНЫХ оТНОПЕНИЙ, 1958) [LENIN ON INTERNATTONAL POLITICS \& INTERNATIONAL LAW (Moscow State Institute of International Relations 1958)]; see also V.I. LENIN, QUESTIONS OF NATIONAL POLICY (Foreign Languages Publ. House 1959) (devoted mainly to self-determination and related questions). In 1970, the Soviet Union issued a volume of Lenin's contributions to international law, edited by Tunkin and V.F. Fedorov. Г.И. ТУНкин, В.Ф. ФеДоров, ред., В.И. ЛЕНИН И СОВРЕМЕННОЕ МЕЖДУНАРОДНОЕ ПРАВО (Москва, Знание 1970) [V.I. LENIN AND CONTEMPORARY INTERNATIONAL LAW (G.I. Tunkin \& V.F. Fedorov eds., Znanie 1970)]. For a short overview of Lenin's contributions to international law, see Г.В. Игнатенко, В. И. Ленин и международное право, 2 ПРАВОВЕДЕНИЕ 98-108 (1970), available at http:/www.law.edu.ru/article/article.asp?articleID=1133126 (Russian).

24. Н.В. МИРОНОВ, ПРАВОВОЕ РЕГУЛИРОВАНИЕ ВНЕШНИХ СНОШЕНИЙ СССР (1917-1970) 7 (ИMO, 1971) [N.V. MTRONOV, LEgal REgulation OF FOREIGN RELATIONS OF THE USSR (19171970) 7 (IMO 1971)] (providing an excellent anthology of legal reforms pertaining to foreign relations bodies in the Soviet Union from 1917-1970).

25. Id. Despite his weakened physical condition, Lenin remained actively involved in executive decisions on matters of war and the status of the USSR in foreign relations. Lenin's responses to ongoing peace negotiations with the Central Powers, for instance, and exchanges between him, Stalin, and Trotsky regarding the Georgia Affair and legal status of Transcaucasian Socialist Federative Soviet Republic showed that he was exceptionally sensitive to how the USSR was being perceived abroad. Id.

26. П.И. Стучка, Ленин и Революиионный декрет, РевоЛЮЦИя ПРАВА 32 (Изд. Ком. Акад., 1925) [P.I. Stuchka, Lenin and the Revolutionary Decree, RevolutsiA PRAvA 32 (1925)] (telling the anecdote that even Stuchka, despite being intimately familiar with Lenin's work, did not know that Lenin was a lawyer until the two of them were buying a printing press in Spring 1917 and Lenin presented his bar card to the seller). 
journals. Third, by 1922 (when these debates began in earnest) Lenin was effectively incapacitated by a stroke caused by an assassin's bullet. Lenin died in January 1924 just as Pashukanis' and Korovin's main treatises were being published.

For these reasons, modern historians and especially legal scholars do not treat Lenin's writings on international law seriously. However, in the context of a Soviet conception of international law and property, Lenin's writings are key to understanding the overarching spirit of pragmatism/realism, while staying true to core Marxist tenets. ${ }^{27}$ Lenin's influence on Soviet international law remained profound in two respects.

First, Lenin explicitly sanctioned the idea of legal instrumentalism, or the notion that law needed to serve a particular policy end. Though law was theoretically indeterminate, unnecessary, and ultimately a bourgeois fiction, ${ }^{28}$ law and legal process were necessary to further the cause of communism in the immediate transition period. This methodology directly influenced an entire generation of pre-WWII and post-war Soviet jurists. Indeed, legal instrumentalism (and perhaps, exceptionalism) in international law would go on to be the Soviets' most enduring contribution to mainstream international law. ${ }^{29}$ Second, how early Soviet jurists rationalized and justified radical departures from Marxist doctrine to carry out diametrically opposed policy reforms sheds light on the Soviets' particular sensibility, or mentalité, concerning law. Understanding this intellectual dynamic can explain not just how Soviets wanted to have their cake and eat it too, that is to say, how Soviet law on the books differed from "law in action." More importantly, by unpacking why and how Soviet Russia betrayed its avowed ideals in exchange for tangible benefits (recognition, material aid, so on), we can better

27. After WWII, scholars attempted to systematize Marx's and Lenin's writings on international law. Notable among these was Tunkin's 1970 work. Г.И. Тункин, В.Ф. Федоров, В.И. Ленин $и$ современное международное право, 2 ГосудАРСТВо и ПРАВо (1970) [G.I. Tunkin, V.F. Fedorov, V.I. Lenin and Contemporary International Law, 2 STATE AND LAW (1970)]; В.Ф. Губин, Карл Маркс и международное право, 2 ГОСуДАРСТВо и ПРАво (1969) [V.F. Gubin, Karl Marx and International Law, 2 STATE AND LAW (1969)]. These journals are not to be confused with the separate periodical of the Institute of State and Law, Sovetskoe Gosudarstvo i Pravo.

28. Roscoe Pound, An Introduction to the Philosophy of Law (Yale 1922). The parallel between Pound's policy-oriented sociological jurisprudence and early socialist legal theory (representative of early Soviet legal realism and American legal realism, respectively) are underresearched and deserve greater scrutiny. For one move in this direction, see generally MICHAEL Head, PAShuKanis: A CritiCal Reappraisal (2004); Lon L. Fuller, Pashukanis and Vyshinsky: A Study in the Development of Marxian Legal Theory, 47 MiCH. L. REV. 1157 (1949).

29. Contemporary scholars trace the theoretical roots of exceptionalism to Carl Schmitt, but Evgeny Korovin's 1924 International Law of the Transition Period arguably influenced Schmitt to a greater extent than has been previously understood. See Korovin, supra note 22. 
understand how the very notions of law, legality, and socialist justice, were co-opted, made indeterminate, and ultimately served as nothing but rhetorical gestures. ${ }^{30}$ Two historical moments illustrate how the early Soviet Union came to recognize and protect intellectual property rights while being ostensibly opposed to law, property, and like "bourgeois notions." First, there was the need to attract foreign trade and project respect for foreign property rights pursuant to international obligations. Second, this need for property protection was internalized into the domestic legal order.

\section{The Dilemma of Attracting Foreign Trade (Pragmatism \& International Law)}

Modern histories of early Soviet law neglect the economic constraints that molded Soviet international legal practice, instead focusing on major events such as Russia's negotiations of the many peace treaties with WWI adversaries and later accession into the League of Nations and subsequent expulsion therefrom. Most scholars list historical and political reasons as lying at the root of Soviet preference for a classic conception of international law (strict sovereignty, anti-monism, etc.). ${ }^{31}$ In international relations, the early years of the Bolshevik state (1918-1920) are commonly seen as when the Soviets developed a foreign policy based on expediency and an ad hoc application of Marxist principles in relations with imperialist states to gain recognition and political legitimacy.

But economic realities had a more direct influence on the shaping of Soviet notions of international law and the place of the Union of Soviet Socialist Republics ("USSR") vis-à-vis the capitalist states. Even hardline Marxist legal theorists like Pashukanis acknowledged how profoundly material conditions would affect the development of Soviet international legal doctrine. As Pashukanis wrote in his brief entry on "peaceful blockades," the Allies, having realized that the Bolsheviks had defeated the counter-revolutionaries, lifted their blockade of Soviet Russia on January 16, 1920 because it was an economic necessity for them to trade

30. Following Prof. Butler, this mentalité, in turn, may bear directly on how contemporary Russian jurists approach law. See Butler, Introduction, supra note 1, at xiii.

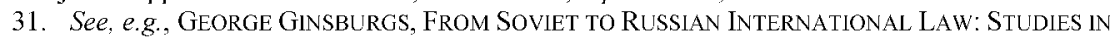
CONTINUITY AND ChANGE (1998); TARJA LANGSTROM, TRANSFORMATION IN Russia AND INTERNATIONAL LAW (2003); Emanuel Margolis, Certain Aspects of the Impact of Communism on International Law at 5-13 (Mar. 1951) (unpublished Ph.D. dissertation, Harvard University, Department of Government). 
with Russia. ${ }^{32}$ Pashukanis was not unique in situating core theoretical disagreements with bourgeois international lawyers in a broader context of trade relations and material conditions, although his position is remarkable in that he framed the discourse in such a way that it appeared the West needed to compromise with the USSR, rather than vice versa. However, prior to any official recognition of the USSR under international law, it was the Soviet Union rather than bourgeois states that was seeking foreign trade. According to Korovin, "[b]y 1921, after the final act of the foreign intervention in the Russian civil war, and the final defeat of Wrangel in 1919-1920, the Soviet Union shifted to negotiations and began seeking compromises and business relationships." 33 "This is not splitting hairs. Since as both Korovin and Pashukanis claimed that material conditions determined the substance of international law, it is important to understand correctly the material conditions of the Russian Soviet Federative Socialist Republic ("RSFSR") and how this affected doctrinal developments.

In fact, despite the high-flying rhetoric of worker's councils, global revolution, and the withering away of law, property, and state, by the early 1920 s, the territory of the former Russian empire lay in economic ruin. ${ }^{34}$ By 1919 , as a consequence of the Great War, the Revolution, the ensuing Civil War, a blockade, the armed allied intervention, and Bolshevik agricultural policies, the Russian economy had essentially flatlined. ${ }^{35}$ In

32. Е. Пашуканис, Мирная Блокада, ЭНЦИкЛОПЕДИя ГОсудАРСТВА И ПРАВА, т. 2, 1002 , 1003 (1925-1926) [Evgeny B. Pashukanis, Peaceful Blockade, in ENCYClOPEDIA OF STATE AND LAW, v. 2, 1002, 1003 (1925-1926)].

33. KOROVIN, INTERNATIONAL LAW OF THE TRANSITION PERTOD, supra note 22, at 60.

34. It is generally agreed that the material situation worsened precipitously from 1917 to 1922 . In Socialist and Imperialist Diplomacy, Chicherin's report to the Fifth Congress in July 1918, he remarks that the goal of Soviet foreign policy was staying on the "revolutionary offensive" while coping with the "unbelievable deterioration" from the effects of the Great War and Tsarism. LENIN \& TROTSKY, The Proletarian Revolution tn Russta 409-10 (1918). Furthermore, this was a period of intense violence and uncertainty in Russia, not only among the general population but also in the diplomatic corps. The assassination of the German ambassador, Count Wilhelm von Mirbach, on April 23, 1918 shortly after his arrival in Moscow, presented a very real legitimacy challenge for the Soviet state. $I d$. at 410 . Economic historians, politicians and literary figures also paint a grim tale regarding Russia's economy during this period. See АЛЕКСЕЙ ТОЛСТОЙ, ХОЖДЕНИЕ ПО МУКАМ (РОМАН ТРИЛОГИЯ), КнИГА 3: ХмУ РОE УТРО (1922-1941) [ALEKSEY TOLSTOY, THE ORDEAL (NOVEL TRILOGY), BOOK 3: BLEAK MORNING (1922-1941)] (describing the social conditions in Russia in the historical period following the Soviet revolution). This image is strikingly similar to Josef Koudelka's famous photo of Prague's Wenceslas Square, nearly empty at noon on August 21, 1968, during the Warsaw Pact invasion of Czechoslovakia.

35. Nikolay Bukharin, Economics of the Transition Period (1920), in THE Politics AND ECONOMICS OF THE TRANSITION PERIOD (K.J. Tarbuck ed., 1979); NikOLAY BUKHARIN, IMPERIALISM AND WORLD ECONOMY (Howard Fennig ed., 1966); Charles Noble Gregory, The International Labor Organization of the League of Nations, 15 AM. J. INT'L L. 42, 49 (1921) "The Soviet press shows that, excluding railroad employees, workers in industry decreased 2,402,000 men up to January, 1919, 
addition, as a result of droughts and crop failures in 1920, Russia encountered a major famine in $1921 .^{36}$

With the failure of communist revolutions in Europe, by 1922 it became clear that "the building of socialism or communism involved industrialization," or a surrender to the hostile capitalists encircling Russia. ${ }^{37}$ On the domestic front, Lenin masterminded the famous (and domestically controversial) ${ }^{38}$ New Economic Policy ("NEP") program, issued by decree on March 21, 1921, to revive the economy. ${ }^{39}$ Yet a lesserknown aspect of NEP was its focus on reviving international trade, particularly with respect to exports of grain and raw materials and imports of industrial machinery. Just as international trade presented a strategic dilemma-restarting international trade meant cooperating with the same hostile capitalists the Bolsheviks had so fiercely opposed-the contradictions between NEP and Marxist theory could not have been greater.

As a further strain on the tensions between Marxist theory and actual Soviet policies, in 1921 the Soviet Union began praying for material sustenance from the "capitalist" West to relieve the effects of the famine. ${ }^{40}$ Then, as now, the United States was one of the first states to respond. By summer 1921, the American Relief Administration ("ARA"), headed by Herbert Hoover, began delivering medical supplies and foodstuffs, along

and a report of the Supreme Council of Popular Economy of March, 1919, states that production in the greater number of Russian industries has decreased 400 to 500 per cent.").

36. FRANK ALFRED GOLDER \& LINCOLN HUTCHINSON, ON THE TRAIL OF THE RUSSIAN FAMINE (Stanford 1927); see also WAR, REVOLUTION, AND PEACE TN RUSSIA: THE PASSAGES OF FRANK GOLDER, 1914-1927 89 (Terence Emmons \& Bertrand M. Patenaude eds., Hoover Press 1992) [hereinafter WAR, REVOLUTION, AND PEACE IN RUSSIA] (describing drought in 1920-1921 and the major famine in Russia stretching from the Volga valley and into southern Ukraine).

37. Alec Nove, Economic Rationality and Soviet Politics; or, Was Stalin Really NECESSARY? 21 (1964).

38. The NEP enveloped and called into question the core premises of the Bolshevik revolution, including the protection of private property, land reform, and accommodation of the bourgeois merchant class.

39. Some Russian sources place this event on March 23, 1921. The decree "On the Replacement of Prodrazvyorstka [Foodstuffs Requisition] by Prodnalog [Foodstuffs Tax]" was issued on March 21, 1921. Seе Декрет ВЦИК, принятий на основе решения Х съезда РКП(б) "О замене разверстки натуральным налогом" (21 марта 1921 г.), available at http:/www.hrono.info/dokum/prod_nal.html (last accessed Oct. 25, 2011); see also Речь Владимира Ильича Ленина «О продовольственном налоге или о продналоге и о свободном обмене хлебных излишков» [V.I. Lenin, On Foodstuff Tax and/or Free Exchange of Excess Wheat Production (Mar. 21, 1921), speech], available at http:// upload.wikimedia.org/wikipedia/commons/e/eb/Lenin_-_About_Natural_Tax.ogg.

40. In July 1921, writer Maxim Gorky (at the behest of Lenin) issued an appeal to "all honest citizens" to send food and medical supplies to Soviet Russia. 
with private aid from workers unions and individuals. ${ }^{41}$ On August 20, 1921, in response to Gorky's call for aid, the ARA and the Soviet government signed the Riga Agreement, which stipulated that the ARA had the "right to control its relief operations inside Russia in exchange for a vow to not mix with Soviet politics."42 Similar agreements were signed with the German Red Cross organizations and other states' relief organizations. ${ }^{43}$ But it was U.S. aid that attracted particular interest and ire from the Soviets.

On the one hand, the ARA aid humiliated the Bolsheviks, who not only resented the notion of imperialists "bailing out" socialists, but were also uneasy about a foreign organization with a sizeable local staff operating throughout much of the country. ${ }^{44}$ The suspicion was shared, though it was ultimately resolved to mutual benefit. ${ }^{45}$ As a matter of international law, Korovin was also alarmed by relief organizations' claims to extraterritorial

41. WAR, Revolution, AND PEACE IN Russia, supra note 36. Golder, an archivist and Director of the Hoover Library at Stanford University, travelled extensively throughout revolutionary Russia. He also served on the American Relief Administration, formerly a government aid agency, but by that time a private relief organization headed by then-Secretary of Commerce Herbert Hoover. Id. at ixxxvi.

42. Id. at 90 (citing Harold H. Fisher, The Famine IN SOVIET Russia, 1919-1923: ThE OPERATIONS OF THE AMERICAN RELIEF ADMINISTRATION (1927)). Archival records reveal the vast scope of the ARA operation:

The initial plan was for the ARA to feed two to three million children, but the mission rapidly expanded to include adults and medical relief as well. The major leap forward came on December 22, 1921, when President Warren Harding signed into law a congressional appropriation of $\$ 20$ million for the purchase of corn and seed grain from U.S. farmers for Russian relief. To this total other government and private U.S. contributions were added (as well as a Soviet government expenditure of nearly $\$ 12$ million from its gold reserve); in the end the two-year ARA program amounted to more than $\$ 60$ million.

Id. $1935)$.

43. Timothy A. Taracouzio, The Soviet Union and INTERnattonal LaW 263 (Macmillan

44. War, Revolution, AND PeACE IN Russia, supra note 36, at 90; see also Korovin, INTERNATIONAL LAW OF THE TRANSITION PERIOD, supra note 22, at 63 (recalling negotiations with "representatives of the International Red Cross, and with personal friends of the American president, vacationing billionaires, and commercial groups"). This resentment echoes Russia's post-2000 turn against the foreign aid establishment.

45. WAR, REVOLUTION, AND PEACE TN RUSSTA, supra note 36 , at 90.

The ARA mission was headed by a career army officer, Colonel William N. Haskell, most of whose U.S. staff had served in the American Expeditionary Force. Many men had attended some of the finest U.S. colleges and universities and had had experience with the ARA in Europe. They were eager to tackle the Russian job with trademark ARA drive and efficiency and had little tolerance for Soviet inefficiency and suspicion; they especially resented the network of Red Army commissars and agents of the secret police set up to monitor their activities. There were many ARA-Soviet confrontations over issues big and small, but each was somehow resolved through diplomacy. In the end the Soviet government officially acknowledged the ARA's contribution in checking the famine and saving millions of lives.

Id. (emphasis added). 
jurisdiction and wrote at length about the need to limit the legal status of foreign charitable organizations operating in the Soviet Union. Writing in the first volume of the journal Sovetskoe Pravo, for instance, Korovin stressed the importance of limiting the rights of foreign organizations operating on Soviet soil, while recognizing the need to set reasonable permissions to aid famine relief efforts. ${ }^{46}$

On the other hand, NEP and foreign aid programs in the early 1920 s certainly worked, as evidenced by the increase in international trade and betterment of material conditions in Russia during that period. Between the years 1921 and 1925, for instance, trade with the United States quadrupled. ${ }^{47}$ During this time, the USSR also entered into a large number of bilateral treaties with European states to normalize trade relations. ${ }^{48}$ Each of these agreements stipulated that the USSR would honor foreign investors' property rights on its territory, in sharp break from the nationalization decrees issued in the immediate aftermath of the Revolution. ${ }^{49}$ To facilitate this process, between 1922 and 1924, the Soviet diplomatic apparatus was restructured to avoid conflicts between the consular representatives abroad and the foreign trade representatives working under the People's Commissariat of Foreign Trade ("NarKomVneshTorg"). ${ }^{50}$ Ten years after the Bolshevik Revolution, the Soviet agricultural and industrial production returned to pre-war (pre-

46. Е.А. Коровин, Иностраная филантропичекая деятельность в РСФСР и ее правовые формы, 1(1) COВЕТСКОЕ ПРАВО 108 (1922) [Evgeny A. Korovin, Foreign Philanthropic Activity in the RSFSR and its Legal Forms, 1(1) SOVIET LAW 108 (1922)]. In his International Law of the Transition Period, he was more direct: "A charitable organization-[such as the Red Cross]-claiming universality over territorial sovereignty of nations is the same legal nonsense as the attempt of a corporation to claim rights under family law." KOROVIN, INTERNATIONAL LAW OF THE TRANSITION PERIOD, supra note 22, at 35.

47. The United States and Soviet Russia signed a "Memorandum on Trade" in January 1921. See

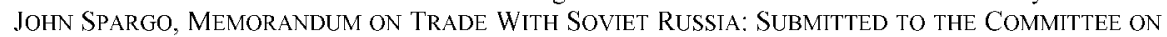
ForEign RELATIONS OF THE UNITED STATES SENATE (1921). These estimates are tentative because significant portions of the increased trade were relief shipments by the United States. See U.S. Bureau of Foreign and Domestic Commerce, Commerce Reports, Vol. 4, at 561 (Oct. to Dec., 1922). In March 1921, the RSFSR also extended the Anglo-Soviet Trade Agreement of March 16, 1921, though disputes with Great Britain over the Wrangell Islands and the intervention led to a slight decrease in trade in 1923.

48. TARACOUZIO, supra note 43 , at $143-50$.

49. Id.

50. Korovin, International Law OF the Transition Period, supra note 22, at 69 (discussing the purpose of the Soviet consulates as being limited to: "(a) protection of economic and legal interests of the RSFSR; (b) official representation of RSFSR and other Soviet organs in the given states; (c) the protection of interests - economic, legal and social of citizens of the RSFSR and its legal entities and firms") (emphasis added). 
1913 ) levels. ${ }^{51}$ By 1930 , Soviet administrators and scholars openly prided themselves on the exponential increase in trade with European powers and with the United States during the 1920s. ${ }^{52}$

The benefits of these bilateral trade treaties, of course, flowed both ways. From the Soviet side, the treaties were conditioned on explicit recognition of the Soviet state under international law. ${ }^{53}$ Therefore, the USSR acquired significant leverage and legitimacy from initiating trade relations. In turn, the bilateral treaties of commerce provided Western European powers and U.S. firms with access to Russian goods and concessions. In essence, the bilateral trade agreements provided mostfavored nation guarantees, "either in its absolute form, or under the form of a conditional (compensational) favoredness, occasionally giving way to preferential regulations more or less extensive in scope. $" 54$ Two concrete examples - the issue of concessions and foreign debt-show the extent to which Soviet leaders bowed to foreign pressure during this time. This, in turn, helps to contextualize the IP reforms in the crucial early years of the Soviet state.

Concessions. Prior to 1928 , the Soviet Union recognized three forms of foreign involvement in the Soviet economy: (1) direct concessions; (2) foreign investment in Soviet firms established pursuant to Soviet law; (3) operation of foreign firms on Soviet soil. ${ }^{55}$ With the start of the first

51. Boris Skvirsky, Russia's Internal Situation and Foreign Policy-Russian-American Trade Relations, 138 AnNALS AM. ACAD. POL. \& SOC. SCl. 97, 99 (1928). Skvirsky's official title before the restoration of diplomatic relations between the United States and U.S.S.R. was that of Director of the Soviet Union Information Bureau, Washington D.C. Id. at 97.

52. Т. Шкловский, Вопросы организации внеиней и внутриней торговли, 7 СОВЕТскОЕ ГОС. И РЕВолюцИЯ ПРАВА 74 (1930) [Т. Shklovsky, Questions of Organization of Internal and Foreign Trade, 7 Sov. Gos. i Revolutsia Prava 74 (1930)]. Shklovsky's article contains useful data on Soviet private, public, and cooperative foreign trade during the period 1923 to 1929.

53. See TARACOUZIO, supra note 43, at 258-60. Taracouzio, however, incorrectly dates the first of the economic agreements between the USSR and Western Powers as being the March 16, 1921 agreement between the USSR and Great Britain. In actuality, the US-Soviet Memorandum on Trade dated January 1921 was the first, though Taracouzio is correct that the Soviet-British agreement served as the model for the subsequent treaties with European powers. These treaties included, inter alia, Provisional Agreement with Germany of May 6, 1921; Provisional Agreement with Norway of September 2, 1921; Treaty of December 7, 1921 with Austria; Provisional Agreement with Italy of December 26, 1921; Provisional Agreement with Sweden of March 1, 1922; Provisional Treaty with Czechoslovakia of June 5, 1922; Agreement with Denmark of April 23, 1923. Id.

54. Evgeny A. Korovin, Soviet Treaties and International Law, 22 AM. J. INT'L L. 753, 754 (1928). By "compensational favoredness," Korovin meant the right of the Soviet state to apply preferential regulations to commerce "with the border states, forming, prior to 1917 , part of the Russian Empire ...." Id. at 756. This theme of regional trade preferences for the near-abroad is strikingly similar to recent regional integration efforts by the Russian Federation.

55. М. Плоткин, Права иностраниев на современном эmane, 3 СовЕТскоЕ ГосудАРСТво 75 (1934) [M. Plotkin, The Rights of Foreigners at the Current Stage, 3 SOVETSKOE GOSUDARSTVO 75 (1934)]. 
five-year plan (1928-1933), the Soviet Union did not award a single additional concession, and sought to restrict existing concessions on the basis of special agreements by purchasing remainder rights from the holders. ${ }^{56}$ The remaining concessions were insignificant. According to Soviet sources, private industry at the end of the first five-year plan represented only $0.07 \%$ of the Soviet industrial output. ${ }^{57}$ Similarly, joint stock companies founded in the USSR with foreign capital during the NEP period were progressively liquidated. During the first five year period, no additional joint stock companies with foreign capital were formed. ${ }^{58}$ The decrees of the Central Executive Committee, dated March 11, 1931, also slightly liberalized the rules pertaining to foreign firms and their representatives operating in the Soviet Union. Pursuant to Article 12 of this decree, firms engaged in negotiations with Soviet trade representatives in Russia no longer had to register and apply for licenses prior to entering into negotiations. ${ }^{59}$

The Soviet international law establishment was fully engaged in support of foreign trade. This is evident not only in the spirit of doctrinal writings such as Korovin's dispatches to the American Journal of International Law, but also in calls for substantive reforms to existing treaties and trade agreements. For instance, by 1930-1931, the Soviet legal academy was mobilized in opposition to a new round of trade tariffs from the United States. Within months of the announcement of Article 307 of the U.S. Tariff Act of 1930 (prohibiting the importation of goods made with forced labor), Soviet international lawyers produced a series of articles critiquing the trade law on general political, as well as substantive, grounds. ${ }^{60}$ The expectation of continued growth in foreign trade during the second five-year plan also required changes in the constitutions of the individual Soviet republics. Extensive protections were afforded to foreign enterprises and their employees operating on Soviet soil. For instance, pursuant to an instruction of the Central Executive Committee dated

56. Id. at 76

57. $I d$.

58. Id. at 77 (discussing liquidation proceedings against the companies Ratao and Sovpoltorg).

59. Id. at 77

60. Экономичиская борьба капиталистических стран против СССР, 3 СОВЕТСкоЕ ГОС. И РЕВОЛЮЦИЯ ПРАВА 113, 117 (1931) [Economic Warfare of the Capitalist States Versus the Soviet Union, 3 Sov. Gos. I Revolutsia Prava 113, 117 (1931)] (proposing the existence of covert economic warfare against the early Soviet Union). Raevich also published an article disputing the American allegations that Soviet goods were produced with forced labor. $I d$. at 127. 
October 3, 1930, foreign workers were granted all formal political rights, including the right to vote. ${ }^{61}$

Foreign Debt. Another external constraint shaping Soviet attitudes on foreign relations and domestic legal reform was the large foreign debt owed to the United States, France, and England, which the Soviet Union inherited from the Tsarist and Kerensky governments. ${ }^{62}$ The original position of the RSFSR was to revoke all debt obligations to Europe and the United States on the basis that these debts were neither incurred by the toiling masses nor on their behalf. ${ }^{63}$ However, debt negotiations formed a major part of early Soviet diplomatic efforts with the West, as evidenced by Chicherin's report of October 28, 1921 and the report of January $1922 .^{64}$ These notes show that Soviet leaders could not sustain their opposition to the debt, as the issue became a major bargaining point of the Western powers towards the USSR. In response, the Soviet delegations slowly gave way on these issues. First, they acknowledged several important distinctions between classes of debt. Pre-1914 debt was acknowledged as possibly valid because it was issued for the purpose of developing Russia's economy, whereas post-1914 debt was issued to sustain the imperial war effort. ${ }^{65}$ Moreover, the Soviet Union countered with a number of offsets, consisting of two classes of claims: (1) for "[t]he value of Russian assets situated abroad"; and (2) for the value of "damages resulting from the Allied intervention ...." By 1925, the Soviet government agreed to pay outstanding debts to European states by modifying a number of terms, including reduction of the amounts of the debt. ${ }^{67}$ The outstanding debt owed to the United States, however, remained unsettled.

Diplomatic notes show the debt to have been a major point of contention between the United States and the Soviet Union well into the mid-1930s. In addition to setting debt repayment as a precondition for

61. Plotkin, supra note 55, at 78 . The favorable treatment of foreign workers (including government subsidies) was meant to demonstrate the equitable work conditions of the Soviet state. Indeed, according to one Soviet scholar, the only distinction between foreign workers and Soviet citizens was simply the conception of "foreignness" - the existence of which was, again, necessitated by capitalist encirclement. $I d$.

62. Kazimierz Grzybowskl, Soviet Public International Law: Doctrines And Diplomatic PraCticE 95-97 (Sitjhoff 1970).

63. The unilateral revocation of all outstanding debts was announced by Lenin in a decree on January 21/February 3, 1918. International Law Reports, 162.

64. GRZYBOWSKI, supra note 62 , at 95-96.

65. Id.

66. Id. at 96 .

67. Id. 
recognition of the USSR, the United States set the following requirements for the USSR to: (1) reject its call for a world revolution and cease propaganda activities; (2) reverse its decree regarding the annulment of international debt obligations (not just United States) ${ }^{68}$ and (3) agree to recognize its international obligations (generally). ${ }^{69}$ The last point-the agreement to recognize general principles of international law-related directly to respect for foreign property rights on the Soviet territory, an issue of central importance to the present discussion. The initial Soviet response was flippant: the Soviet Union did not need any legal or de facto recognition from the West. ${ }^{70}$ However, this posture was disingenuous, as the Soviet Union certainly sought recognition from the United States, and the Soviets were expending great diplomatic efforts to win U.S. recognition. ${ }^{71}$

In international law, Korovin justified the Soviet debt annulment by reference to his class/transition theory - essentially arguing that the Soviet social revolution created a radically new legal form that was qualitatively different from other states. ${ }^{72}$ Korovin admitted that ordinarily any successor state was bound by the legal and financial obligations of its predecessor, but refused to acknowledge the Soviet debt on the basis of communist principles. Diplomatic history and the facts of the actual debt service by the Soviet state reveal a slightly different story.

First, it is important to understand that the Soviet state initially continued to service (pay interest on) the debt, even following the decree on annulment. ${ }^{73}$ This supports the theory that the Soviet Union sought to

68. The debt was partly due to the enormous increase in Russian-American trade (primarily exports from the United States to Russia during WWI). See George F. KEnnan, The Decision to INTERVENE 323-24 (Princeton 1958) (discussing the influence of private American interests on the decision to intervene, including American-Russian Chamber of Commerce composed of bankers (A.B. Hepburn), industrialists and "[t]hirty to forty other firms").

69. Id. at 20 .

70. Id.

71. This position is surprising because the Soviet Union had worked exceedingly hard at gaining recognition of European powers. The stance vis-à-vis the United States may have been a negotiating tactic, but it certainly did not resemble the prior negotiation efforts.

72. Korovin, International Law Of the Transition Period, supra note 22, at 30.

73. Interestingly, in 1987 a class action case was decided in which a firm sued the Soviet Union in a U.S. district court under the Foreign Sovereign Immunities Act ("FSIA") to recover part of the debt $(\$ 75$ million, representing a $\$ 25$ million issue in 1916 and a $\$ 50$ million issue by the Tsarist government in 1917). See Carl Marks \& Co. v. USSR, 665 F. Supp. 323 (S.D.N.Y. 1987), aff'd per curiam, 841 F.2d 26 (2d Cir. 1988), cert. denied, 487 U.S. 1219 (1988). The court denied the claim, holding that the FSIA would not apply retroactively to the Imperial-era bond issue. Carl Marks \& Co., 665 F. Supp. at 337. After reviewing case law, the court also held that as late as 1926, the USSR (like any foreign sovereign) would have expected absolute immunity from suit in the United States. Id. at 339. The USSR had a justified expectation that it would not be retroactively sued in the United States. The case is noteworthy for its succinct retelling of the relevant facts of the debt issue. Id. at 324-32. 
project adherence to international norms and bilateral agreements even when they ran counter to the professed ideology. ${ }^{74}$ Perhaps more importantly, servicing the debt intended to signal that the Soviets would be reliable members of the international community and good faith trade partners despite theoretical squabbles with the West. For the following fifteen years, while the Soviet Union publicly espoused Korovin's position-arguing that the debt was not legally binding on the USSR, as it was carried out contrary to the wishes of the proletarian class-Soviet diplomats privately emphasized that the debt would be settled and that the USSR would fully comply with all international obligations. ${ }^{75}$

On November 16, 1933, the Soviet state publicly agreed to repay the debt in exchange for recognition by the U.S. and being allowed to join the League of Nations. To save face and maintain theoretical consistency, the debt settlement agreement between President Roosevelt and the USSR People's Commissar for Foreign Affairs Litvinov did not expressly stipulate that the USSR would repay debt incurred by the Kerensky government. Rather, the agreement employed a creative legal device (which came to be known as the Litvinov Assignment). The USSR would pay $\$ 9$ million in pre-inflation money to the United States in exchange for an assignment of all claims, including those due it as the successor of prior governments of Russia, "on condition that it be notified of any recovery by the United States on such claims." 76

Why did the USSR agree to repay the obligation when most historians agree that it could have chosen not to recognize the debt? ${ }^{77}$ Unclassified diplomatic dispatches between then-U.S. Ambassador to the USSR Joseph Davies and the U.S. State Department shed light upon the matter. ${ }^{78}$ On the topic of debt owed to the United States, Ambassador Davies stressed the symbolic significance to the Russians of repayment. The amount of the loan itself was, in the words of Davies,

74. Interest was paid on the remaining three installments of the bond certificates on July 10 , 1918 , January 10,1919 , and July $10,1920 . I d$. at 326 . Interest was also paid on the bearer bond coupons due on June 1, 1918, December 1, 1918, and June 1, 1918 [sic]. Id.

75. U.S. Department of State, Records Relating to Political Relations Between the United States and the Soviet Union, The National Archives of the United States 1934 [Cornell Library Microfilm, Film 5863, Roll 1] (containing diplomatic dispatches from Joseph Davies, U.S. Ambassador to the Soviet Union) [hereinafter Davies].

76. Carl Marks \& Co., 665 F. Supp. at 326-27. For a discussion of similar claims against the Soviets, see Alexander Nahum Sack, Diplomatic Claims Against the Soviets (1918-1938), N.Y.U. LAW Q. REV. 507 (1938).

77. The amount of the indebtedness was approximately $\$ 200$ million in 1933 dollars (when it was settled for $\$ 9$ million). The original amount was approximately $\$ 75$ million from two issues. It was held in bearer bonds and credit participation certificates.

78. See Davies, supra note 75 . 
of relative unimportance of the matter to the United States and the supreme importance to the Russian people of having in the future a body of liberal public opinion in the United States sympathetic to the Russian people, particularly in view of the uncertain international situation [the threat of war]. ${ }^{79}$

Indeed, since by the early 1930s the Soviet Union began to seriously contemplate the threat from fascist regimes; paying off the minor debt in an effort to curry favor with the significantly more powerful U.S. government seemed to have been a reasonable step toward balancing the deteriorating relationship with Germany. This was all the more true because by 1933, Stalin's position was sufficiently entrenched to the extent that he would not really lose political capital domestically for settling the debt issue. In any event, it is clear from the negotiations that "it was a serious matter to [Russia] to retain the confidence of the [U.S.] government in the performance of the [debt settlement] agreement ....",0 One can surmise several other likely motivations. First, Soviet leaders began to realize the immense economic potential of trading with the U.S. and other developed countries in order to further accelerate industrialization. Second, with Soviet acquisition of Ford automobile and tractor manufacturing plants, metal refineries, and general technical knowhow, measurable progress in the manufacturing sector meant moving away from the status of a raw material exporter. The Soviets thereby improved global standing and gave greater support to the possibility of "socialism in one country. $" \$ 1$

The subjective element in the debt negotiations should also be noted. As Davies remarked, the Soviet diplomats went out of their way to impress upon him (with personal guarantees and gestures) that the Soviet Union would pay the debt. Likewise, Davies, in both his official and personal capacities, made a great deal of the humanitarian similarities between the United States and the Soviet Union. In his words:

[The U.S.] did have a great body of humanitarian democratic thought which did have great influence upon world opinion among liberal minded men everywhere which might be of inestimable

79. Id. at 15 .

80. Id. at $63-64$

81. Of the over 2,500 treaties that Soviet Russia concluded during the first forty year period of its existence (1917-1957), the majority concerned economic problems and questions, chiefly matters of trade and commerce. See Jan F. Triska \& Robert M. Slusser, The Theory, LAw, and Policy of SOVIET TREATIES 4-5 (1962) (providing an excellent overview of Soviet treaty practice during early Soviet period). 
value to Russia at some point in the future; and that speaking as a friend of the humanitarian impulses and purposes of the Russian people, personally I felt compelled to say that in my opinion it would be a great pity if a cloud were to be permitted by the Soviet government to dim the confidence which my government might have in the integrity and character of the men who were running affairs here; that this was particularly true in my opinion because there was no leadership of any of the great nations of the earth that viewed with as much sympathy the fundamental humanitarian purposes of the Russian people to the degree that President Roosevelt and Secretary of State Hull did; that it would be too bad if a condition were to be permitted by the Soviet government to exist which would dampen or destroy their confidence in the integrity of leadership; that financial credits and business considerations in importance faded into nothing in contrast with this matter of the principle involved. [The Soviet Union] is producing enormous agricultural and mineral wealth annually, and it will not be dependent upon import or export for many years to come. ... While there is no question but what, in its present phase, its efficiency cannot compare with capitalist states and possibly never will, nevertheless, in the absence of competition or necessity for competition with capitalist states, such inefficiencies need not and will not appear. ${ }^{82}$

From the Soviet side, Marshal of the USSR and staunch Stalin ally Kliment Voroshilov" agreed that the financial amount involved "was relatively small" and urged to settle the matter on "big broad, general principles and that a way should be found, that he appreciated the greatness of the President of the United States." 84 Aside from subjective factors, ${ }^{85}$ Voroshilov and Litvinov's desire to see the debt matter settled on

82. Davies, supra note 75 , at 64 .

83. Voroshilov was appointed People's Commissar for Military and Navy Affairs and Chairman of the Revolutionary Military Council of the USSR, a post he held until 1934, when he was elevated to Marshal of the Soviet Union.

84. Davies, supra note 75, at 64 (Moscow, February 18, 1937-Dispatch No. 68 [Ambassador Davies to Secretary of State Hull]).

85. There are many such factors in the diplomatic notes, and they call for a critical reexamination, both generally, as well as part of a "rehabilitation," so-to-speak, of Davies who was branded "too soft" on the Communists by critics. For instance, it is noteworthy to observe the nearobsequiousness of the Soviet leaders in their interactions with Davies. In one example, President Kalinin warned Ambassador Davies of superficial snap judgments of Russia, "A visitor might see some drunkenness on the streets of Moscow and therefore draw the conclusion that all Russians are 
"broad principles" was highly consistent with the body of Soviet treaty practice that had developed by that time. This can be summarized as follows:

(1) Protection of foreign property rights in the USSR via bilateral trade agreements;

(2) Diplomatic assurances that the USSR treated investment and property claims as apolitical "administrative" issues governed by private international law;

(3) Increasing emphasis that competition with "bourgeois" states was a matter of ideological difference, rather than an actual political posture. $^{86}$

Of the three, the most important vehicle for the promotion of foreign trade was projecting a predictable treaty regime. But demonstrating the strength of domestic property rights regimes and enforcement mechanisms was a close corollary.

Korovin wrote extensively on this subject in his treatises and journal articles. ${ }^{87}$ In his International Law of the Transition Period, for instance, he emphasized that treaties were the sole source of international law and were sacrosanct in Soviet practice (though not in theory). ${ }^{88}$ In his 1927 article on treaties, he explained that treaties formed a backbone of Soviet foreign practice and were inviolable, save to further advance the cause of communism. ${ }^{89}$ The Soviet diplomatic corps was instructed to emphasize that the Soviet Union, in addition to rejecting secret diplomacy, had never violated a single treaty. Aside from projecting a predictable treaty regime and respect for international norms to attract investment, the Soviet Union also incorporated international customary and conventional law on the

drunkards, which, of course, was not the fact." Id. at 28 (Moscow, Jan. 25, 1937-Dispatch No. 11 [Ambassador Davies to Secretary of State Hull]).

86. See id. at 103-05 (Moscow, Mar. 12, 1937-Dispatch No. 116 [Ambassador Davies to Secretary of State Hull, titled "Russian Industry - How It Works and Why"]) (emphasis added).

87. See, e.g., Е.А. Коровин, К пересмотру “Женевской Конвении," 15(3) СоветскоЕ ПрАво 52 (1925) [Evgeny A. Korovin, Reexamination of the Geneva Convention, 15(3) SovIET LAW $52(1925)]$.

88. Е.А. Коровин, Оговорка rebus sic stantibus в межоународной практике Р.С.Ф.С.Р., 6(3) Советское ПрАво 53 (1922) [E.A. Korovin, The Principle Rebus Sic Stantibus in International Practice of the RSFSR, 6(3) SOVIET LAW 53 (1922)] (upholding the classic conception of rebus sic stantibus principle and doctrine of necessity for violating positive treaty obligations).

89. Е.А. Коровин, Советские договоры и межоународное право 30(6) СОВЕТскоЕ ПРАВО 91 (1927) [Evgeny A. Korovin, Soviet Treaties and International Law, 30(6) SOVIET LAw 91 (1927)]. 
protection of property in its domestic legislation. This issue is central to the present vertical harmonization analysis.

\section{The Dilemma of Reconciling Communism, NEP \& IP}

Attracting and protecting foreign trade in the Soviet Union necessarily required the adoption of domestic laws to protect property, since without security, Western firms simply would not invest in Russia. ${ }^{90}$ Korovin and subsequent Soviet authors treated the protection of property under international law as questions of international administrative law, as apolitical issues on which cooperation with the West was not only permissible, but encouraged. ${ }^{91}$ Notwithstanding the centrality of property rights to domestic legal battles and theoretical debates, international protection of property rights, as in the case of intellectual property, was seen by Soviet theorists as a foreign policy issue, and hence subordinate to more pressing foreign trade-related policy discussions. For instance, despite not adhering to the Berne Convention of $1886^{92}$ or the revision to the treaty signed at Berlin in $1908,{ }^{93}$ the early Soviet state took tremendous pains to signify its protection of foreigners' copyright, patents, and trademarks. This was done principally by harmonizing Soviet domestic legislation with international customary and conventional lawtantamount to participating in the given treaty bodies, without actually

90. See, e.g., Н.В. МИРОНОВ, ПРАВОВОЕ РЕГУЛИРОВАНИЕ ВНЕШНИХ СНОШЕНИЙ СССР (19171970) 275 n.29 (UMO, 1971) [NIKOLAI V. MiRonov, LEGAL REGULATION OF ForEIGN RELATIONS OF THE USSR (1917-1970) 275 n.29 (IMO 1971)] (discussing a decree issued by the NKID on May 23, 1919, "[o]n the Prohibition of Protection of Property of Foreigners from States Which Have Severed Diplomatic Relations with RSFSR"); Н. БЕРНШТЕЙН, Б. ЛАНДАУ, В. МАШКЕВИЧ, ПРАВОВЫЕ УСЛОВИЯ КОНЦЕССИОННОЙ ДЕЯТЕЛЬНОСТИ В СССР 26-47 (M: 1930) [I. BERNSTEIN, B. LANDAU \& V. MASHKEVICH, LEgal CONDITIONS OF CONCESSIONS IN THE USSR $26-47$ (M: 1930)].

91. See Korovin, Contemporary Public International Law, 98-102. It is curious that Western legal historians have not focused more on this aspect of Soviet law and the contradictions between Marxist conceptions of private property, Lenin's formulation of state capitalism, and Stalin's foreign trade relations policy. It seems the contradiction concerning property and Soviet trade and concessions with Western firms was much more fertile soil for pointing out contradictions in Soviet theory and practice than revisiting the abstract debates concerning the nature of law.

92. The Berne Convention removed registration requirements to trigger copyright protection, and codified continental conceptions of moral rights. Berne Convention for the Protection of Literary and Artistic Works, Paris Act, arts. 2-3, 6 bis, July 24, 1971, 1161 U.N.T.S. 3 (amended Sept. 28, 1979); TARACOUZIO, supra note 43 , at $154 \mathrm{n} .93$. The United States opposed the Berne Convention because of the removal of registration requirements. By contrast, as indicated above, the USSR removed domestic registration requirements, without formally acceding to the Berne Convention.

93. See TARACOUZ1O, supra note 43 , at 154 n.93. 
doing so. ${ }^{94}$ We can trace this process by observing the evolution of Soviet domestic legislation on authors' rights.

Authors' Rights. Between 1924 and 1931, there were almost yearly radical changes to the IP regulatory framework and the administrative organs charged with implementing the laws. ${ }^{95}$ The earliest Soviet law concerning authors' rights and patent rights was a decree in 1917 nationalizing all such rights "in the interest of government," with limited protection for the authors. Pursuant to this decree, the duration of authors' rights was limited to six months, after which all rights reverted to the state. $^{97}$

Ivan Peretersky, writing in the journal Sovetskoe Pravo, analyzed these domestic legislative changes in the field of authors' rights following the Bolshevik revolution. ${ }^{98}$ What is immediately striking regarding these reforms was that they occurred so soon after the revolution. The first proposed decree on authors' rights was issued on December 6, 1917, just one month after the Bolsheviks gained control. ${ }^{99}$ Pursuant to this proposal, the length of the protected term was reduced to fifteen years, followed by a five-year period where the copyright ${ }^{100}$ was held by the state if the People's Commissariat of Enlightenment found it to have aesthetic or scientific value. ${ }^{101}$ The proposal was not adopted. Instead, an even more restrictive regime was adopted by decree on December 29, 1917, monopolizing authors' rights in favor of the state for a period of five years. ${ }^{102}$ Furthermore, on June 11, 1918, a decree was issued on the abolition of the inheritance of authors' rights, except in the case of heirs below the age of majority or incapable of working (нетрудоспособные

94. This strategy is remarkably similar to the IP reform efforts of the Russian Federation to comply with TRIPS throughout the 2000 s without being a signatory or member of the WTO, an issue that will be discussed infra.

95. Галина Витальевна Довгань, Система государственныхх органов и обиественных организаиий в сфере изобретательства в УССР (1924-1931 гг.) [Galina V. Dovgan', System of State Organs and Social Organizations in the Sphere of Patent Protection in the Ukrainian SSR (1924-1937)], available at http://www.lomonosov-msu.ru/archive/Lomonosov_2008/28_4.pdf.

96. John N. Hazard, Notes on Economic Law (Prof. Amfitiatrov, 1936) at 90 (Manuscript Collection, Columbia University Libraries, Bakhmeteff Archive).

97. Id.

98. И. Перетерский, Задачи Советского законодательства в области авторстого права, 4(1) COBETCKOE ПРАВO 92 (1923) [I. Peretersky, Goals of Soviet Legislation in the Field of Author's Rights, 4(1) SOVIET LAW 92 (1923)].

99. Id. at 92 .

100. I shall use the terms "copyright" and "author's rights" interchangeably. The term "author's rights" is the preferred term in the Soviet literature (as well as in continental jurisprudence more generally), but the concepts and legal ramifications are identical.

101. Peretersky, supra note 98 , at 92 .

102. Id. 
[disabled]). ${ }^{103}$ Shortly thereafter, on November 26, 1918, another decree was issued "nationalizing scientific, literary and artistic works," 104 remaining in force until 1923.

Pursuant to this decree, any work (published or unpublished) could be claimed by the state as its property. ${ }^{105}$ The relevant state agency then had the right to publication, reproduction, and public exhibition of the work. ${ }^{106}$ The author was entitled to an honorarium, and in the case of minor children, remainder rights could be paid out to the heirs from the proceeds of the work. ${ }^{107}$ The author's right expired six months after death. ${ }^{108}$ Interestingly, in regulations promulgated by the People's Commissariat on Enlightenment on February 9, 1919, the old fifty-year terms were used for works created prior to the nationalization, or specifically, June $1,1919 .^{109}$

These conflicting decrees were systematically reworked following the introduction of NEP, not only to protect domestic authors, but also to incorporate international protections for the defense of foreign authors. Peretersky indicates that more than one year went into the drafting of the new law on authors' rights. ${ }^{10}$ This new law was intended to be a departure from the Russian Imperial Code of 1911, both in substance and spirit, but Peretersky's account points to tension within the Institute of Soviet Law in the drafting of the new code. ${ }^{111}$ First, much like American opposition to the Berne Convention on the basis of moral rights, drafters had difficulty conceptualizing precisely what was being protected-whether it was the abstract "spiritualized" right of the author to his or her creation or the work product of this spiritual, "psychological" process. ${ }^{112}$ Moreover, there were proposals to discard this distinction, as well as the distinction between authors' rights and patents over physical inventions, in favor of a broad principle protecting quite simply, products of labor, consistent with Marxist ideology. ${ }^{113}$ After discussing at length the legal distinction between patents and authors' rights, Peretersky conceded the need for

103. Id.

104. Id.

105. Id.

106. Id.

107. Peretersky, supra note 98 , at 92 .

108. Id.

109. Id. at 93 . In addition, by decree dated August 16, 1921, all textbooks were to be published by the state publishing house ГосНздат (Gosizdat). Id.

110. Id.

111. Id. at $93-94$.

112. Peretersky, supra note 98, at 93-94.

113. Id. at 94 . 
different terms and legal protection regimes, though the goal, in principle, was a single unitary system. ${ }^{114}$

Peretersky's Marxist critique of copyright law illuminates how Soviet theorists balanced individual versus (what they considered) new social rights. ${ }^{115}$ According to Peretersky, the state had rights to the given work because the actual creator of the work was not merely the individual author, but also the social medium in which he or she worked. ${ }^{116}$ Next, since copyright, like all law, was not a logical but a historical construct, copyright law had to take into account relevant economic relations of production and the social utility of given works. ${ }^{117}$ However, it is remarkable to observe the workings of the NEP and the hold of the capitalist mindset, as Peretersky concludes that defense of authors' rights was necessary to protect the incentives for the creation of works-a proposition completely incompatible with Marxist thought. ${ }^{118}$ Thus, Peretersky proposed reintroduction of all Imperial-era rights, such as the author's right to prevent alteration of his or her "mental child," the right of reproduction, and the right of compensation for takings. ${ }^{119}$ To the extent that the government retained rights, these had to be limited so that the state could not seize works for commercial benefit. ${ }^{120}$ With respect to the objects of copyright, Peretersky suggested sweeping categories, including traditional works, but also new works stemming from the introduction of film (Peretersky suggested copyright over plotlines to films, whether they were written or not). ${ }^{121}$ Lastly, Peretersky suggested the introduction of a uniform template publication agreement (between publishers and authors) modeled on the Swiss contract code of 1911, subjecting publication contracts to the statute of frauds. ${ }^{122}$

Peretersky's discussion elided conflicts of laws issues and international treaties, but these became major points of contention in subsequent writings. With economic growth came the decree of 1925, which established longer duration terms, ${ }^{123}$ but maintained the widest possible

114. Id.

115. Id. at 95

116. Id.

117. Id. at 94-95.

118. Peretersky, supra note 98 , at 95.

119. Id. at 96 .

120. Id. at 97

121. Id.

122. Id. at 99 .

123. Butler, Intellectual Property Law in the Russian Federation, supra note 5, at xivxy. 
state use and public use exceptions, such as translation of foreign works without compensation. ${ }^{124}$

Furthermore, the Soviet Union took a favorable position on the Berne Convention (continuing the Imperial legacy). ${ }^{125}$ The Berne treaty regime was affirmed in bilateral treaties with a number of European states. For example, the Soviet-German treaty "on the defense of industrial property" dated October 12, 1925 required the USSR to apply German law and IP protections in dealings with German citizens and firms. ${ }^{126}$ Despite recognizing the Berne protections, the Soviet Union entered into a number of separate agreements where the USSR claimed broad state-use exemptions in the "use of the technical and cultural heritage of the West," which Korovin justified by reference to the "[Soviet] material and cultural paucity."127

The 1925 set of fundamental principles on authors' rights was expanded in 1928, and ultimately codified in the Law on Author's Rights of October 8, 1928. Pursuant to this law, the author's right expanded from 25 years from the date of publication or presentation, to the life of the author, plus fifteen years after the author's death. In the opinion of Soviet jurists, these copyright terms were entirely consistent with international norms. ${ }^{128}$ Soviet jurists were of the same opinion on the related harmonization process with respect to trademarks and patents. ${ }^{129}$

In fact, by 1935, Pashukanis dropped any opposition to international conventions for the defense of industrial or property rights. ${ }^{130}$ In formalist fashion, he wrote about the International Council for the Defense of

124. Hazard, supra note 96 , at 90 .

125. Korovin, CONTEMPORARy Public INTERnational LAw, supra note 91, at 100.

126. Id. at 99 .

127. Id. at 100 .

128. Id.

129. NEP and post-NEP Soviet legislation fully protected domestic and foreign trademarks in accordance with bilateral and general principles outlined in international agreements. Writing on trademarks in 1924, S.I. Raevich began his article with a note on how "fortunate" it was that trademarks received sufficient legislative attention both during the period of war communism and the NEP and remarked how consistent Soviet patent legislation was with European standards. С.И. Раевич, O mоварнылх знаках по советскому праву, 12(6) Советское ПрАво 64 (1924) [S.I. Raevich, On Trademarks in Soviet Law, 12(6) SOVIET LAW 64 (1924)]. With the adoption of the law "On Patents on Inventions" in 1924, the committee on inventions under the Supreme Soviet of the National Economy (BCHX CCCP) continued functioning, but its prerogative was greatly restricted to issuing applications, licenses for the use of models, shop drawings and trademarks. Dovgan', supra note 95 , at 1 . The patent system introduced in 1924 created a patent bureau and required users to obtain permission of the patent owner prior to using the invention. Id. (citing BCHX CCCP №11 oT 25.11.1925).

130. Е. ПАШУКАНИС, ОЧЕРКИ ПО МЕЖДУНАРОДНОМУ ПРАВУ 165-66 (Гос. ИЗД. Сов. Законодательство, 1935) [E. PASHUKANIS, ESSAYS ON INTERNATIONAL LAW 165-66 (State Publ. Soviet Jurisprudence 1935)]. 
Industrial Property rights founded in Berne in 1883 (pursuant to the 1883 Paris Convention for the Protection of Industrial Property). ${ }^{131}$ To Pashukanis, these "special questions of international law" and international administrative unions were to be analyzed based on a concrete estimate of their expected utility. ${ }^{132}$ He saw no danger or conflict between these special treaty bodies and overarching Soviet principles, so long as they did not signify the wholesale adoption of bourgeois systems or conflation into the League of Nations apparatus. ${ }^{133}$

Whereas to the early Pashukanis, the debate over property concerned the basic form/substance distinction and the legal notion of property (including socialist property concepts in Soviet law) was but a sham for what was in essence bourgeois law, ${ }^{134}$ by the late 1920 s scholars like Korovin succeeded in showing that it was permissible to use seemingly bourgeois constructs during the transition stage to communism. Both Korovin and Pashukanis reconciled the seeming contradiction between intellectual property protection and Marxist theory by situating both in a broader international law and foreign policy context. Whereas lesser figures like Dotsenko continued to struggle to create a theoretical distinction between private property and personal property - where private property was deemed to be that which was acquired as a result of commercial enterprise (as for instance, under NEP), and personal property was that acquired as a result of work in a communal enterprise (such as the Kolkhoz) ${ }^{135}$-Korovin's notion of the transition theory and instrumentalism obviated the need to ground intellectual property discussions in more fundamentally theoretical terms. To put it another way, protecting intellectual property rights was indispensable to attract trade, and trade was indispensable to strengthening the Soviet state; likewise, whatever was necessary to strengthen the Soviet state was consistent with Marxist-Leninist tenets. This position was solidly endorsed by Pashukanis' successor, Andrey Vyshinsky, ${ }^{136}$ and continued to serve as

131. Id.

132. Id. at 165 .

133. Pashukanis observed that Article 24 of the Statute of the League subordinated existing treaty bodies to the League. $I d$. at 164-65. However, aside from the expressed desire to see these bodies separate, Pashukanis offers no discussion of the interaction of the various administrative organs and the League.

134. See generally PASHUKANIS, LAW AND MARXISM: A GENERAL THEORY, supra note 6

135. Id. at 9

136. Michael Head, The Passionate Legal Debates of the Early Years of the Russian Revolution, 14 CAN. J. L. \& JURISPRUDENCE 3, 27 (2001) (discussing Vyshinsky's arguments in defense of law and "stability of laws" by reference to property rights: "[Vyshinsky's examples of the need for law] all concerned the protection of private property interests. 'To reduce law to policy would be to ignore 
the basis for the Soviet "stability of laws" doctrine for the remainder of the Soviet Union.

\section{Late Soviet IP Protection: An Overview}

Having discussed the centrality of the property rights and vertical harmonization debates in the creation of the early Soviet state, it is worthwhile to explore the late or "classic" Soviet treatment of IP law. This section provides an overview of this phase of the Soviet IP regime, including the USSR's participation in international conventions concerning intellectual property.

In the domestic realm, Soviet copyright law resembled European civil law authors' rights protections, with a major distinction being the goal of the law. From the Soviet perspective, Soviet copyright law sought to balance the rights between authors and "society," whereas Western law was seen as being unfavorably biased towards publishers against authors. $^{137}$ However, despite this rhetorical position, Western commentators writing on Soviet copyright law stressed the similarities to European regimes. Western comparativists routinely remarked on the Soviet's relatively unremarkable, and even "unexciting,"138 distinctions with respect to Western copyright law, contrary to what one would expect from a socialist state. Unlike Cuba's complete disavowal of copyright law in the $1960 \mathrm{~s},{ }^{139}$ for instance, the Soviet Union fully ascribed to reigning international obligations throughout its existence (whether by conforming domestic law to international standards, or by joining the relevant treaties).

On the international plane, the Soviet Union was a state party to the three principal conventions relating to authors' rights from the mid-1970s: the Berne Convention on the Protection of Literary and Artistic Works as amended in 1971; the Universal Copyright Convention ("UCC") as amended in $1971^{140}$ (the USSR ratified the UCC in 1973); and the 1971

such tasks confronting law as that of the legal defense of personal, property, family and inheritance rights and interests, and the like." ").

137. Dietrich A. Loeber, "Socialist" Features of Soviet Copyright Law, 23 ColuM. J. TRANSNAT'L L. 297-98 (1985) [hereinafter Loeber] (offering an excellent introduction to Soviet copyright law).

138. Id. at $298-302$.

139. Id. at 302-03 (quoting Fidel Castro Speaks, 214, 218 (1969)). Cf. Ley No. 14 de 28 de diciembre de 1977, Ley del Derecho de Autor, available at http://www.cenda.cu/php/loader.php?cont $=$ legis.php\&tipo=2 (harmonizing Cuban copyright law with international standards).

140. Universal Copyright Convention as revised at Paris on 24 July 1971, with Appendix Declaration relating to Article XVII and Resolution concerning Article XI 1971, July 24, 1971, available at http://portal.unesco.org/en/. 
Convention on Protection of the Interests of Producers of Phonograms Against the Illegal Reproduction of their Phonograms. The major legal maneuver exercised by the USSR concerned its accession to the UCC in 1973. The Soviet Union adopted the UCC before the 1971 Paris amendments to the UCC went into force, ${ }^{141}$ so as to avoid the 1971 amendments which gave authors greater exclusive rights to their work and significantly restricted legal licenses. ${ }^{142}$

On February 21, 1973, six days before the USSR deposited its declaration of accession to the UCC, the Presidium of the Supreme Soviet of the USSR enacted a series of amendments to chapter IV of the 1961 Fundamentals to bring the Soviet copyright law in line with the minimum requirements the UCC imposed. ${ }^{143}$ Ultimately, in 1978 the USSR acceded to the Paris amendments, subject to a reservation granting liberal use of Soviet works by developing countries. The political justification for the USSR acceding to the treaties was explained in a separate letter (1978) from the USSR to the treaty body:

Desirous of helping to create favorable conditions for the use of the works of Soviet authors by the developing countries for educational purposes, the Union of Soviet Socialist Republics agrees to the application of the aforementioned Convention to the works of Soviets [sic] authors. ${ }^{144}$

With its accession to the UCC, scholars observed that a seemingly dual system of copyright law emerged. For works published by domestic authors (or works by foreigners which were first published on USSR territory), the Soviet copyright legislation applied. On the other hand, international law governed copyright rights for foreign works. As analyzed by Michiel Elst, the consequences of this dual system of copyright were felt particularly in the limitations of copyright. ${ }^{145}$ Thus, domestic authors' rights were subject to the most far-reaching free uses and legal licenses,

141. See ELST, supra note 5 , at 82 n. 147.

142. Id. An amendment made at the Paris diplomatic conference in 1971 pertained to Article VI bis (1) \& (2) relating to reproduction, public use, and transmission of works by radio. See M.M. Boguslavskil, Private International Law: The Soviet ApproaCh 173 (William Simons trans., 1988); see also Records of the Conference for Revision of the Universal Copyright Convention: Unesco House, Paris, 5 to 24 July 1971 (Unesco 1973).

143. See ELST, supra note 5, at 82-83.

144. Supra note 140 (Universal Copyright Convention, with Appendix Declaration relating to Articles XVII and Resolution concerning Article XI 1952, UNESCO Convention Documents, Protocol 2 (letter from the USSR dated August 24, 1978)).

145. ELST, supra note 5, at 95 . 
whereas those who fell within the purview of the UCC enjoyed broader protection.

This dual system had noticeable practical effects. For instance, if a musical work of a Soviet writer was publicly performed, it could be freely reproduced in a film or freely broadcast on radio and television. On the contrary, public performance of a work by a foreign author did not subject the author to the free use exemptions or legal licenses of Soviet law: the author's permission was required ${ }^{146}$ because the extent of fair use/legal license use in the domestic context was quite broad, ${ }^{147}$ especially for educational or scientific purposes. ${ }^{148}$ However, with the Soviet state often the copyright holder, and in many instances the ostensible copyright encroacher, copyright issues in the domestic arena were mostly moot. ${ }^{149}$ With respect to traditional copyright protection issues (length of term, etc.), Soviet domestic implementation of the UCC was consistent with international standards. ${ }^{150}$ The term of protection was twenty-five years after the death of the author with remainder rights paid out to heirs, much like in capitalist states. ${ }^{151}$

Elst correctly notes that the foreign-domestic duality in Soviet copyright law was untenable. However, when Soviet jurists recognized this discrepancy, their solution was to simply adapt the much broader free use standards found in Soviet copyright law to international law, and not vice versa. ${ }^{152}$ In other words, consistent with the USSR's political and cultural policy, reconciling "fair use" between Soviet law and international norms often meant adopting the wider fair use exemptions. For purposes of the present analysis, this can be rephrased as rejection of vertical harmonization. By insisting on its own legal standards, the Soviet Union

146. See id. at $95-99$.

147. Id. It was also expanded domestically in 1973 to permit newspapers to reproduce any published report or scientific, artistic, literary, or oral work; either in the original or as a translation. Michael A. Newcity, COPyright LAW in THE SOVIEt UniOn 110 (Praeger 1978). This was used famously by Soviet literary journals to publish translations of Vonnegut's Breakfast of Champions and Norman Mailer's Marylin. Due to highly-publicized protests from the West, the Soviet Union bought publishing rights to the works shortly thereafter. $I d$. at 111-12.

148. NEWCITY, supra note 147 , at 112 .

149. Serge L. Levitsky, Copyright, Defamation, and Privacy in Soviet Civil Law: De Lege Lata AC Ferenda, No. 22(I): LAW in EASTERN Europe 420-21 (Martinus Nijhoff 1979) (listing instances where copyright claims could not be invoked against the state pursuant to Soviet civil law limitations despite being enumerated as fundamental constitutional or traditional author's rights).

150. Loeber, supra note 137 , at 299-300.

151. Id. at 300 ("As to the property rights of the deceased - the royalties-comparative lawyers would expect some 'socialist' impact on the law, such as the denial of monetary benefits to an heir on the grounds that these would accrue to him as 'unearned income.' Soviet law, however, stops short of imposing such a limitation and conforms in this respect to capitalist practices.").

152. ELST, supra note 5, at 101 
was maintaining an exceptionalist posture on the issue of broad fair use protections.

With respect to actual enforcement of copyright claims against the Soviet Union, it should be noted that very few claims (foreign or domestic) actually proceeded through the Soviet judiciary. Peter Maggs, in his introduction to the copyright volume of Soviet Statutes and Decisions, explained that this was due to the realities and context of state publishing. ${ }^{153}$ The limitation on who could actually publish authors' works and control the revenues and royalties indeed presented a serious limitation on the free exercise of rights, although some transfers did occur. ${ }^{154}$ Moreover, in the domestic context, copyright infringement claims were limited by the remedies available to aggrieved parties through Soviet civil, labor, and administrative law, representing the interplay between the three major characteristics of the Soviet system: socialist property, economic planning, and the leading role of the Communist Party. ${ }^{155}$ With respect to foreign claims, interpretation of obligations arising under international treaties was rare due to the small number of potential disputes involving foreign claimants.

By the mid-1980s, advances in technology required the modernization of Soviet IP law (as in other countries) to reflect the challenge posed by new digital reproduction technologies. During this time, like most legal systems, the Soviet system only sporadically investigated the challenges posed to copyright by technical advances. ${ }^{156}$

\section{RUSSIAN IP LAW (1992-2006): TRANSITION}

\section{A. Change, Transplants, and Harmonization}

After the collapse of the Soviet Union, Russia's IP regime underwent a radical series of transformations. Generally speaking, they can be divided into three periods. The first, lasting from 1992 to 1994, was a period of indigenous change with law reform proposals originating from working groups established in the dying days of the USSR. The second period,

153. Loeber, supra note 137 , at 312 (citing 14 SOVIET STATUTES AND DECISIONS 5 (P.B. Maggs ed., 1977-78)).

154. Id. at $303-12$.

155. Id.

156. ELST, supra note 5, at 109 
roughly from 1995 to 2006 , was a period of legal transplantation ${ }^{157}$ and vertical harmonization. ${ }^{158}$ Here, vertical harmonization characterizes the relationship between Russia and international trade bodies like the WTO, as well as the perception of more diffuse norms or general principles of international law. ${ }^{159}$ This period is notable because it coincided with what Gianmaria Ajani identified as the second stage of transition and law reform in Russia, "marked by a more critical approach towards 'paper laws' and by a more conscious attitude towards the 'Anglo-American thinking' of legal advisers and of international financial institutions." "160 Because IP reform in Russia followed other reforms, this period may also reveal how Russian policymakers internalized the lessons of preceding reforms in other substantive fields, if at all. Lastly, the third period of IP reform corresponds to the adoption of Part IV of the Russian Civil Code on November 24, 2006 (effective January 1, 2008), intended to supersede all previous legislation relating to intellectual property and to bring Russian law into compliance with international obligations.

Scholars have chronicled the evolution of Russia's IP regime in exceedingly detailed accounts, ${ }^{161}$ so there is no need to retell the reform process, save but in general strokes. As a state successor to the USSR, the Russian Federation remained a state party to each of the treaties discussed above. ${ }^{162}$ Aside from inheriting Soviet treaty obligations, the Russian Federation was also heir to a new Soviet intellectual property law which was to go into effect in the USSR on January 1, 1992, but actually went into force in the new Russian Federation on August 3, 1992. This

157. See Alan Watson, Legal Transplants: An Approach to Comparative LaW (1974); Gianmaria Ajani, By Chance and Prestige: Legal Transplants in Russia and Eastern Europe, 43 AM. J. COMP. L. 93, 93 n.1 (1995).

158. Peter Maggs, The Process of Codification in Russia: Lessons Learned from the Uniform Commercial Code, 44 MCGILL L.J. 281 (1999).

159. See Larry Catá Backer, Introduction and Analysis, in HARMONIZING LAW IN AN ERA OF Globalization: Convergence, DivergenCE, AND Resistance 13-14 (Larry Catá Backer ed., 2007) (discussing vertical integration, and citing the definition of harmonization as the "effect [of] an approximation or co-ordination of different legal provisions or systems by eliminating major differences and crating minimum requirements or standards").

160. Ajani, supra note 157 , at 96.

161. See generally ELST, supra note 5.

162. In 1994, Victor Chernomyrdin issued a governmental decree to clarify that Russian Federation inherited its international treaty obligations with respect to IP. See Russian Federation, decree no. 1224/1994: О присоединении Российской Федерации к Бернской конвенции об охране литературных и художественных произведений в редакции 1971 года, Всемирной конвенции об авторском праве в редакции 1971 года и дополнительным Протоколам I и 2, Конвенции 1971 года об охране интересов производителей фонограмм от незаконного воспроизводства их фонограми, November 3, 1994 (Russian) [Governmental decree no. 1224 from 1994, signed by Viktor Chernomyrdin, Regarding Russia's Accession to the Berne Convention, UCC, and the 1971 Additional Protocols to the UCC], available at http://www.copyrighter.ru/full/index.html?berne4.htm. 
legislation lasted only one year before being replaced by the Law on Author's Rights and Neighboring Rights, which went into force on August $3,1993{ }^{163}$

In a clean break with the Soviet past, the 1993 Russian Constitution also recognized and protected by law "intellectual property" as an aggregate of exclusive rights to the results of intellectual activity. ${ }^{164}$ The use of the term "intellectual property" versus authors' rights is significant as it was the first time the term was used in Russian legislation since the early 1920s. As relevant to the discussion below, the Russian Constitution also enshrined additional limited guarantees with respect to mass information. For instance, Article 29(4) provides: "Each shall have the right to freely seek, receive, transmit, produce, and disseminate information by any legal means." ${ }^{165}$ Similarly, Article 29(5) provides that "[t]he freedom of mass information shall be guaranteed." These rights must be interpreted in light of the copyright law, and vice versa, but Russian courts have yet to rule on any likely conflicts. ${ }^{166}$

Equally important, the 1993 Russian Constitution codified a monist conception of international law. ${ }^{167}$ Article 15, Section 4 proclaimed that general principles of international law, customary international norms and international agreements to which Russia is a party shall henceforth be constitutive norms of the Russian legal system. ${ }^{168}$ Pursuant to the plain

163. William E. Butler, intellectual Property LaW N THE RUSSiAN Federation, supra note 5, at xvi; see also id. at 15 (providing an English translation of the 1993 law).

164. See Konstitutsiia Russiiskoi Federatsii [Konst. RF] [CONSTITUTION] art. 44, available at http://www.gov.ru/main/konst/konst 1 1.html.

165. Id. art 29(4); WiLliam E. BuTLER, RusSian LAw 710 (2d ed. 2003) (providing an English translation of 1993 Russian Constitution).

166. The above provisions respecting freedom of information have been interpreted to refer to the government's duty to release information. However, as explained fully below, this provision may also be read more broadly to suggest a protection of the means of access to mass information, such as the Internet. For instance, such a broad protection may be employed to immunize Russian Internet service providers from their customers' copyright violations.

167. In the USSR, the relationship of treaties to municipal law was one of the most hotlycontested issues in international law. One view was that the act of ratification of a treaty by the Presidium of the USSR Supreme Soviet was "a special normative act imparting legal force to international treaty norms." William E. Butler, Comparative Approaches to International Law, 190 RECUEIL DES COURS 9, 52-53 (1985). Another view held that transformation of national legislation was necessary before an international treaty became part of municipal law. $I d$. at 53 . Third, according to Article 21 of the 1978 USSR Law on the Procedure for the Conclusion, Execution, and Denunciation of International Treaties, certain treaties became automatically binding upon incorporation pursuant to Article 21. Id.

168. Konstitutsiia Russiskoi Federatsii [Konst. RF] [CONSTITUTION], Art. 15, available at http:// www.gov.ru/main/konst/konstll.html (“Общепризнанные принципы и нормы международного права и международные договоры Российской Федерации являются составной частью ее правовой системы. Если международным договором Российской Федерации установлены иные правила, чем предусмотренные законом, то применяются правила международного договора." 
language of Article 15, international treaties were elevated higher even than domestic legislation: under Section 4, if an international convention contravenes other laws, then the international convention trumps domestic law. ${ }^{169}$ Article 15 , Section 4 itself did not stipulate whether international law required national implementation, translation, or transformation, or whether international treaties are self-implementing. ${ }^{170}$ Accordingly, the constitutional provision immediately became the locus of a major debate in post-Soviet international legal theory. ${ }^{171}$ This debate, by and large, has continued to the present day. ${ }^{172}$

Returning to the copyright law, the 1993 Law on Author's Rights and Neighboring Rights was not well received by either Russian scholars or Western observers. While the law recognized individuals' property rights in cultural and artistic works of their own creation, it considerably reduced the list of free uses, a longstanding custom in Soviet IP law. Remaining free uses were defined much more narrowly than before, and compulsory licenses were abolished altogether. ${ }^{173}$ From the West's viewpoint, the 1993 law reform package lacked many of the basic elements found in Western practice, such as the right to alienate and encumber intellectual property rights. ${ }^{174}$ Accordingly, the legislative package was quickly tabled for amendment. Incidentally, this was to have positive consequences, as it allowed legislators to assess the impact of emerging information

["General principles and norms of international law, and international treaties to which Russian Federation is a party, are constitutive parts of Russia's legal system. If national law contradicts international treaties, then international law supersedes national legislation."]).

169. Id.

170. В.В. Гаврилов, Теории трансформачии и имплементации норм межсународного права 6 отечественной правовой доктрине. 2 МоскоВскИЙ ЖУРНАЛ МЕЖДУНАРОДНОГО ПРАВА 39-61 (2001) [V.V. Gavrilov, Theories of Transformation and Implementation of International Legal Norms in Russian Legal Doctrine, 2 Moscow J. INT"L L. 39, 40 (2001)], available at http:/www.law.edu.ru/ article/article. asp? articleID $=162606$.

171. Е.Т. Усенко, Соотноиение и взаимодействие международного и национального права u Российская Конституция, 2 МОскОВСКИЙ ЖУРНАЛ МЕЖДУНАРОДНОГО ПРАВА 16 (1995) [Е.Т. Usenko, Correlation and Interrelationship of International and Domestic Law and the Russian Constitution, 2 Moscow J. INT'L L. 16 (1995)]; В.В. Гаврилов, Теории трансформачии и имплементации норм международного права в отечественной правовой доктрине. 2 МОСКОВСКИЙ ЖУРНАЛ МЕЖДУНАРОДНОГО ПРАВА 39, 39-61 (2001) [Gavrilov, supra note 170, at $39-61$.

172. See K.N. Ratsiborinskaia, Application of International Law by Russian Courts, in RUSSIAN LAW: THEORY \& PRACTICE 59 (2004); O.A. Ishchenko \& E.G. Ishchenko, Implementation of International Law in Russian Legislation, 2 RUSSIAN LAW: THEORY \& PRACTICE 196 (2008); L.L. Ponomareva, International Law in Decisions of Russian Criminal Courts, 1 RUSSIAN LAW: THEORY \& PRACTICE 52, 55-59 (2008) (discussing the Surgut District Court's failure to consider international standards and extradition rules, and proposing legislative changes to require courts to explain analytical process in court decisions).

173. ELST, supra note 5, at 370-75.

174. Id. 
technologies and to compare similar reform projects then being proposed in various jurisdictions, as well as internationally.

The Russian civil code was incrementally amended in 1995 and 2004 to further conform Russian domestic law with evolving TRIPS ${ }^{175}$ and bilateral obligations. ${ }^{176}$ Generally speaking, the 1995 and 2004 reforms kept with longstanding Soviet practice and the civil law tradition. Rights were based on the moral theory of authors' rights; that is, an author has exclusive rights to use his works, including the rights of reproduction, distribution, "communication to the general public by cable," and others (all referred to as the "property rights"). The copyright law applied broadly to any work, whether technical, artistic, or of another nature, and also to all reproducible media. ${ }^{177}$ The 2006 reform also added to the list of exclusive rights an "Internet right" - that is, the right of "communication of a work in such a way that it is accessible for any person in the interactive mode from any place and at any time at his choice (right of making available to the general public)." 179 A limited fair use exemption was provided in Articles 20-24 covering traditional cultural, educational, and scientific uses. ${ }^{180}$ Part IV of the Russian Civil Code was adopted in 2006 and became effective on January 1, 2008.

These reforms were meant to be evolutionary and to gradually modernize and bring Russian law in line with international norms.

175. See Agreement on Trade-Related Aspects of Intellectual Property Rights, April 15, 1994, 33 I.L.M. 1197 (1994) [hereinafter TRIPS Agreement].

176. Sergey Budylin \& Yulia Osipova, Is AllofMP3 Legal? Non-Contractual Licensing under Russian Copyright Law, 7 J. HiGH TECH. L. 1, 3 n. 16 (2007).

177. In addition to the General Law on Author's Rights, there also exists a 1992 Law on the Legal Protection of Programs of Electronic Computers and Data Bases (as amended 24 December, 2004). See William E. Butler, Intellectual Property in the Russian Federation, supra note 5, at xxii. Pursuant to this law, "[c]omputer programs are treated as works of literature, and data bases, as collections." Id. The substantive provisions of the law are similar to the Law on Author's Rights. Id. A Russian Agency for the Legal Protection of Computer Programs, Data Bases, and Topologies of Integral Microcircuits was formed to register computer programs, data bases, and topologies and contracts assigning such (pursuant to the 1992 law on Computers and Data Bases, amended in 2004). Id. at xxii-xxiii. However, it is unclear how many computer programs were or are voluntarily registered with this agency.

178. In 2006, the Supreme Court of the Russian Federation issued an advisory opinion seeking to clarify the then-existing copyright law, delineate civil and criminal jurisdiction, procedure and evidentiary rules, and highlight the need for further reform as a result of challenges posed by the Internet. See Supreme Court of the Russian Federation: $O$ вопросах, возникиих у судов при рассмотрении гражданских дел, связанных с применением законодательства об авторском nраве и смежсных праваx, Plenum decision no. 15 of June 19, 2006 [On Questions Regarding the Application of the Copyright Law], available at http://www.supcourt.ru/vscourt_detale.php?id=4349.

179. See Budylin \& Osipova, supra note 176 , at 4 (this provision went into effect on September 1 , 2006, but has since been superseded by Part IV of the Russian Civil Code).

180. 1993 Law on Author's Rights and Neighboring Rights, Arts. 20-24 (author's translation). 
However, aside from mandatory harmonization required by Article 15(4) of the Russian Constitution, Russia also sought to voluntarily harmonize its domestic IP regime with WTO-related IP norms. Yet how did Russia interpret these obligations? To what extent did Russia succeed in coordinating its domestic legal regime with TRIPs? These questions can be analyzed through Russia's evolving conceptions of fair use/free license in copyright policy. Fair use is a useful analytical frame because it illustrates where a legal regime strikes the balance between individual rights to a given work and social or public rights. For instance, if during Soviet times legal doctrine avoided the term "intellectual property" altogether-criticizing it "for not only its inaccuracy but for being bourgeois and exploitative" $" 181$ and provided fairly broad fair use exceptions to copyright, analyzing fair use in the post-Soviet context elucidates the continuities/changes between Soviet and post-Soviet sensibilities ${ }^{182}$ towards intellectual property more broadly.

Prior to embarking on the fair use analysis, however, a review is necessary of the driving forces, both domestic and international, behind the harmonization reforms.

\section{B. Policy-Driven Harmonization (2000-Present)}

Effective January 1, 2008, Russia's entire intellectual property regime was codified in a new Part IV of the Russian Civil Code. ${ }^{183}$ The stated purpose of Russia's new Part IV of the Civil Code ("New Copyright Law") was to bring Russian copyright law into line with international copyright norms. ${ }^{184}$ The express goal was harmonization of Russia's entire IP regime - not merely individual normative acts, but the entire regulatory and enforcement system-with the standards set forth in multilateral conventions, namely TRIPS, but also other conventions. ${ }^{185}$ The law reform

181. William E. Butler, INTELlectual Property LAW IN THE RUSSIAN FEDERATION, supra note 5 , at $\mathrm{x}$.

182. "Sensibility" here refers to the opinions of legal scholars and policymakers regarding a given proposition. Research has revealed no opinion polls or ethnographic data on the topic of intellectual property rights in the late 1980s and early 1990s from the perspective of Soviet citizens. The assertions, therefore, are based on logical inferences, doctrinal writings and a small unscientific opinion sample from Russian colleagues.

183. Alexander L. Makovsky, On the Fourth Part of Russia's Civil Code, in CIVLL CODE OF THE Russian Federation, Fourth PART 24 (Peter Maggs \& Alexander Makovsky eds., 2008) (offering a parallel English-Russian translation).

184. GRAZHDANSKII KODEKS ROSSLISKOI FEDERATSII [GKRF] [Civil Code] pt. 4, available at http://www.internet-Law.ru/law/kodeks/gk4.htm (Russ.).

185. V.N. Monakhov, Conference Presentation at Moscow State University Faculty of Journalism: Mass Information in Internet: Freedom and Responsibility (Oct. 12-13, 2007). A draft version of the 
project followed more than ten years of advisory work from the United States, the WTO and international IP organizations. ${ }^{186}$ The reform project was championed by a number of domestic actors, such as the Moscow Media Law and Policy Institute and media industry groups, who sought to clarify the confusing maze of rights and obligations under previous legislative enactments. But a foreign lobby also took active part in shaping the new law. A common overarching political reality for both camps was that perceived success/failure of the reforms would influence Russia's accession to the WTO. ${ }^{187}$

\section{WTO, TRIPS \& the American Lobby}

Russia's long road to WTO membership began almost twenty-five years ago. Even under the Soviet Union, one of the first steps of the Gorbachev administration was to apply for membership to the GATT in August 18, 1986, and to participate in the Uruguay Rounds, both of which were rejected by the West. ${ }^{188}$ The Russian Federation reapplied for GATT membership in 1993, one year after the dissolution of the USSR. ${ }^{189}$

present section was presented at the conference. Sample treaties include the Berne Convention for the Protection of Literary and Artistic Works (Sept. 9, 1886, last amended 1979), in force in the Russia Federation since March 13, 1995; Brussels Convention Relating to the Distribution of ProgrammeCarrying Signals Transmitted by Satellite (May 21, 1974), in force in Russian Federation since January 20, 1989; Madrid Agreement for the Repression of False or Deceptive Indications of Source on Goods (Apr. 14, 1981) (revised at Washington on June 2, 1911, at The Hague on November 6, 1925, at London on June 2, 1934, and at Lisbon on October 31, 1958 and was added to in Stockholm on July 14, 1967); Paris Convention for the Protection of Industrial Property (Mar. 20, 1883, last amended 1979), in force in Russian Federation since August 12, 2009; Patent Law Treaty (Sept. 1, 2000), with currently signed parties, in force in Russian Federation since August 12, 2009; Convention for the Protection of Producers of Phonograms Against Unauthorized Duplication of Their Phonograms (Oct. 29, 1971), with 80 currently signed parties, in force in the Russian Federation since March 13, 1995; Rome Convention for the Protection of Performers, Producers of Phonograms and Broadcasting Organizations (Oct. 26, 1961), in force in Russian Federation since May 26, 2003; Trademark Law Treaty (Oct. 27, 1994), with 77 signers, and which the Russian Federation signed May 11, 1998; Washington Treaty on Intellectual Property in Respect of Integrated Circuits (May 26, 1986), the ten signers of which include Zambia, Serbia, Saint Lucia, Liberia, India, Guatemala, Ghana, Egypt, China, Bosnia and Herzegovina; WIPO Copyright Treaty (Dec. 20, 1996); WIPO Performances and Phonograms Treaty (WPPT) (Dec. 20, 1996).

186. Ольга Плешанова, Гражданский кодекс разоиелся с требованияли ВТO, Коммерсанть (24.07.2006) [Olga Pleshanova, Civil Code Departs from Demands of WTO, Kommersant (July 24, 2006), available at http://www.kommersant.ru/doc.aspx?DocsID=692256.

187. Russia in the international Context: Private international law, Cultural Heritage, intellectual Property, Harmonization of Laws, Festschrift for Mark M. BogusLavskiJ (A. Trunk, R. Knieper A.G. \& Svetlanov eds., Berliner Wissenschafts-Verlag 2004).

188. KAZIMIERZ GRZyBOWSKI, SOVIET INIERNATIONAL LAW AND THE WORLD ECONOMIC ORDER 187 (1987).

189. Elmira Danelyan, Russia's Long Journey to the WTO: Whose Interests Will Be Served if Russia Joins the World Club?, 1:4 LANDSLIDE 52, 52 (2009). 
Russia's WTO accession process has been tumultuous, and reflects many of the broader anxieties about liberalization reforms in Russia over the past twenty years. This is not the place to delve into the large amount of literature on Russia and the WTO, ${ }^{190}$ but a review of the debate over TRIPS $^{191}$ and IP reform is necessary.

Russia's IP regime first gained widespread global attention around the late 1990 s and early 2000 s, when a vocal opposition to Russian piracy, coupled with lax IP regulation, began to take shape in the West. ${ }^{192}$ The West's criticism had several roots. First, Russia's large, highly educated and technologically savvy work force (diminished and, perhaps, emboldened by the "brain drain" of the 1990s) began to use the Internet to download vast amounts of copyrighted Western-sourced media, including video games, computer programs, films, music, and electronic books. Second, around the late 1990s, the rate of high-profile hacking, spamming and phishing attacks originating from Russia began to multiply exponentially. These attacks raised public awareness of the danger posed by emerging technologies, especially in light of the then-impending Y $2 \mathrm{~K}$ crisis. A third publicized source of tension between America and Russia was America's allegation that the Russian government was complicit in its public's obsession with Internet piracy by completely disregarding its obligations to protect copyright with respect to new and emerging technologies. ${ }^{193}$ This was seen as stemming from weak enforcement mechanisms, corruption, low penalties, and "lack of education and training for law enforcement and judicial officials." "194

190. Chiedu Osakwe et al., Russia's Accession to the WTO, CARNEGIE ENDOWMENT FOR INTERNATIONAL PEACE (Dec. 10, 2009), available at http://www.carnegieendowment.org/events/?fa= eventDetail\&id=1496; see also Jasmine Cameron, WTO Accession and Legal Tradition in the Area of Intellectual Property Rights: A Comparative Case Study of Kyrgyzstan and Russia, $11 \mathrm{~J}$. EAST ELROPEAN LAW 1 (2004); Mike Moore, Director-General, World Trade Organization, speech at the Fifth Annual Russian Economic Forum: Russia and the WTO: Reintegration in the World Economy (Apr. 19, 2002), available at http://www.wto.org/french/news_f/spmm_f $/$ spmm84_f.htm; Harry G. Broadman, Russian Trade Policy Reform for WTO Accession, 401 WORLD BANK DISCUSSION PAPERS 41, 51-53 (1999); Christian L. Broadbent \& Amanda M. McMillian, Russian and the World Trade Organization: Will TRIPS Be a Stumbling Block to Accession?, 8 DUKE J. COMP. \& INT'L L. 519 (1998).

191. The TRIPS Agreement, in concordance with the general WTO regime, prohibits intellectual property laws from offering any benefits to local citizens which are not available to citizens of other TRIPS signatories.

192. See David E. Miller, Combating Copyright Infringement in Russia: A Comprehensive Approach for Western Plaintiffs, 33 VAND. J. TRANSNAT'L L. 1203, 1220-22 (2000).

193. Id. at $1207-12$.

194. Hearing to Explore Permanent Normal Trade Relations for Russia: Before the Subcommittee on Trade of the House of Representatives, Committee on Ways and Means, 107th Cong. 48 (2002) (statement of Thomas R. Pickering, Senior Vice President, International Relations, Boeing). 
A common sentiment among Western observers in the early to mid2000 s was that among the world leaders in global music piracy, Russia had one of the largest piracy problems in the world because of inadequate laws and enforcement mechanisms. ${ }^{195}$ Despite a computer-literacy and population growth rate that was a fraction of China's, the Russian threat was perceived as equaling, if not exceeding, China's. This was partly due to China's earlier adoption of IP regulations (China joined the WTO in 2001), but may also have reflected Cold War-era mistrust and apprehension. Rhetoric from American industry groups like the Recording Industry Association of America (RIAA) and political leaders bears this out. In 2005, for instance, Senator Orrin Hatch (R-UT) stated that, before he would vote on Russia's accession to the WTO, "many of us will have to be convinced that the Russian government is serious about cracking down on theft of U.S. intellectual property." the United States contended that Russian law does not provide TRIPSconsistent protection against unfair commercial use of test data and other data submitted to obtain marketing approval for pharmaceutical and agricultural chemical products. ${ }^{197}$ The 2006 annual U.S. Trade Representative "Section 301" report, for instance, refers to deficiencies which include: the "lack of an effective and deterrent criminal enforcement system . . . ; the lack of effective plant inspection [for optical media production and distribution] . . ; the lack of civil ex parte search procedures; an extremely porous border; delays in criminal prosecutions and adjudications; and infrequent destruction of seized pirate goods.",198

To overcome this impasse, in November 2006, United States and Russia signed a "market access agreement" requiring Russia to take action to address piracy and make continuing law reforms before the Unites States would consent to Russia joining the WTO. ${ }^{199}$ In a side letter to the market access agreement, the United States singled out Russian optical

195. Michael Mertens, Thieves in Cyberspace: Examining Music Piracy and Copyright Law Deficiencies in Russia as it Enters the Digital Age, 14 U. MiAmt INT'L \& COMP. L. REV. 139, 143 (2006); see also Russia loses WTO bid as G8 begins, 16 July, 2006, available at http://news.bbc .co.uk/2/hi/europe/5183892.stm (describing Bush-Putin talks prior to G8 summit relating to enforcement of Russian laws against the piracy of American music, computer programs, and DVDs).

196. Bradley S. Butterfield, Kevin J. Mason, Joseph B. Payne, and Robert R. Trumble, Human Resources and Intellectual Property in a Global Outsourcing Environment: Focus on China, India, and Eastern Europe, 15 INT'L H.R. J. 7 (2006).

197. 2005 OfFice of U.S. TRADE Representative Special 301 Report.

198. Id. at 32; Laurence R. Helfer, The New Innovation Frontier? Intellectual Property and the European Court of Human Rights, 49 HARV. INT'L L.J. 1 n.218 (2008).

199. Susan Butler, U.S. Labels Target Russian Music Site, BILlBoARd, Jan. 27, 2007, at 17; Office of U.S. Trade Representative, Fact Sheet, Results of Bilateral Negotiations on Russia’s ACCESSION TO THE WORLd TRAdE ORganization (Nov. 19, 2006). 
media (CD, DVD, etc.) factories and Internet servers that manufactured or distributed foreign copyrighted works, calling on the Russian government to aggressively target these offenders. ${ }^{200}$ In exchange for Russia's agreement to step up enforcement and to streamline the passage of Part IV of the Civil Code, the United States promised to provide further training and advisory support for the Russian Ministry of Economic Development and Trade. ${ }^{201}$

Notwithstanding the market access agreement and assurances from Russian leaders, losses from IP infringement originating in Russia continue to rise. An annual report compiled by the Office of the U.S. Trade Representative pursuant to Section 182 of the U.S. Trade Act of 1974 provides a glimpse into the alleged losses from copyright infringement in countries like Russia. ${ }^{202}$ In 2009 alone, the estimated losses from Russian piracy of business software were nearly $\$ 1.9$ billion. $^{203}$ In sum, the American copyright industry estimates that it loses at minimum $\$ 2.5$ billion dollars to Russian piracy each year. These figures do not include estimates for losses of records and music, motion pictures, entertainment software, and books. Consequently, the U.S. Trade Representative maintains Russia on its "Priority Watch List." By comparison, losses due to Chinese piracy (with its significantly larger population and computer and internet access rates) amount to $\$ 3.5$ billion. $^{204}$

200. Office of U.S. Trade Representative, U.S. Russia Bilateral Market access Agreement-Side LetTer on InTellectual Property Rights (Nov. 19, 2006), available at http://ustraderep.gov/assets/World_Regions/Europe_Middle_East/Russia_the_NIS/asset_upload_file1 48 10011.pdf; Bilateral Market Access Agreement on Intellectual Property Rights, U.S.-- $\mathbf{R} u s s i a$, available at $\mathrm{http} / /$ ustraderep.gov/Trade_Sectors/Intellectual_Property/Russia/Section_Index.html.

201. Office of U.S. Trade Representative, U.S. Russia Bllateral Market access AgreEMENT-Side LeTter oN INTElLectual Property Rights (Nov. 19, 2006).

202. The "Special 301" Report is an annual review of the global state of intellectual property rights (IPR) protection and enforcement, conducted by the Office of the United States Trade Representative (USTR) pursuant to Section 182 of the Trade Act of 1974, as amended by the Omnibus Trade and Competitiveness Act of 1988 and the Uruguay Round Agreements Act (enacted in 1994). See 19 U.S.C $\$ 2101(2006)$.

203. These statistics are compiled by the International Intellectual Property Alliance (IIPA) and incorporated into the Special 301 Report. See IIPA, SPECTAL 301 REPORT 126 (2010), http:/www.ijpa .com/rbc/2010/2010SPEC301RUSSIA.pdf. By comparison, the 2008 losses from Russian piracy of business software were nearly $\$ 2.3$ billion. Id. Globally, annual American losses due to IP violations amount to more than $\$ 100$ billion, according to one U.S. trade group, the Coalition Against Counterfeiting and Piracy (headed by NBC VP Rick Cotton). See Darrell A. Hughes, NBC VP: US Needs Intellectual-Property Rights Protection Plan, WALl St. J., Feb. 18, 2010, available at http:// online.wsj.com/article/BT-CO-20100218-714295.html.

204. Id. 


\section{Russian Civil Code (Part IV) and Legal Licenses}

The following section outlines several substantive provisions relating to legal licenses and fair use, and compares them with established American fair use standards to determine the extent of likely actual harmonization. The U.S. copyright law and fair use exemption are chosen as a functional equivalent ${ }^{205}$ because of the vast number of American cases interpreting and applying the fair use doctrine and the dominance of the U.S. approach in international IP regulation regimes. Copyright infringement claims in Russia and the United States also often arise from similar factual circumstances, especially in cases involving copyright infringement on the Internet.

To begin, Article 1245 of the Civil Code of the Russian Federation (all subsequent article references are to the New Copyright Law) governs the reproduction of copyrighted works in the form of "home copies"-limited copies of copyrighted musical works for private use. Even "home" reproduction of such musical works must be compensated. As before, copyrighted musical works are protected more strictly than other audiovisual electronic works, notwithstanding the fact that, currently, more and more books, academic materials, and other works containing scientific, artistic, photographic, or other non-musical works take the form of electronic, easily reproducible works. The distinction between musical and other audiovisual electronic works made in Article 1245 illustrates the ambiguity of the current scheme. Thus, the traditionally protected right to "home copy" musical works for personal archive needs is eliminated, while home reproduction of non-phonographic or non-musical works is allowed. Such ambiguities abound in the new law.

For instance, Article 1266 protects authors' rights to prohibit alterations of their works. ${ }^{206}$ Pursuant to this law, the author's written permission is required to make any additions, alterations, deletions, provision of illustrations, to issue a preface, postscript, or add comments or explanations to a text. In short, all alterations of a work are prohibited without the author's express consent, save the separately preserved right for parodies and caricatures. Article 1266 marks a strong departure from the previous right against alteration. Currently, the author's right to his or her "reputation" is invoked solely in instances where the alterations may have caused an infringement on the author's reputation or honor.

205. See Graziadei, supra note 4.

206. These rights are properly titled the rights of inviolability over a given copyrighted work (права на неприкосновенность произведения). 
Similarly, Article 1273 provides for a limited "private use" exemption. Pursuant to this Article, reenactment of a copyrighted work is permitted so long as it is strictly performed for private use. ${ }^{207}$ However, like Article 1245 (Right to "Home Copy"), the private use exemption is ambiguous on its face. Applied to the Internet context, the implications of this provision become even more unclear. First, the term "reenactment" (воспроизведение) does not clearly define a particular set of permissible rights or acts. Secondly, "private use" is notoriously fuzzy when applied to the Internet. For instance, is posting a clip of copyrighted music on a private Internet message board so that the individual can enjoy clips of the music remotely considered private use, or is the fact that the music clip is reproduced and hosted on a remote server sufficient to constitute illegal reproduction?

Article 1274 contains a limited "cultural use" exemption." ${ }^{208}$ This section provides a legal license for free use of copyrighted material in "informational," scientific, educational, or cultural contexts. Although the educational and cultural exemption seems broad, the exemption itself is subject to several very broad limitations. For instance, pursuant to Article 1274 Section 2, libraries may lend electronic versions of copyrighted works (CDs, DVDs, VCR cassettes, e-books) only so long as the works are viewed in library facilities, under conditions making reproduction impossible. Immediately, such a limitation bans legitimate

207. Seе Статья 1273 (Свободное воспроизведение произведения в личных целях допускаетея без согласия автора или иного правообладателя и без выплаты вознаграждения воспроизведение гражданином исключительно в личных целях.) [Grazhdanskii Kodeks Rossiiskoi Federatsii [GKRF] [Civil Code] art. 1274 (Russ.) (allowing the free right of reproduction for private use without the permission of the author or the holder of author's rights and without compensation.)].

208. Id. art. 1274 (allowing the free use of copyrighted works for informational, scientific, educational/teaching and cultural purposes).

[...]

2. В случае, когда библиотека предоставляет экземпляры произведений, правомерно введенные в гражданский оборот, во временное безвозмездное пользование, такое пользование допускается без согласия автора или иного правообладателя и без выплаты вознаграждения. При этом выраженные в цифровой форме экземпляры произведений, предоставляемые библиотеками во временное безвозмездное пользование, в том числе в порядке взаимного использования библиотечных ресурсов, могут предоставляться только в помещениях библиотек при условии исключения возможности создать копии этих произведений в цифровой форме.

[2. When a library offers samples of works that have been legally introduced into public use, for temporary non-profit use, this use is allowed without the consent of the author, the holder of the author's rights, and without compensation. Electronic copies of works, including works introduced for reciprocal use of resources, may be lended only in the library facilities and under conditions prohibiting the possibility of creation [reproduction] of these works in digital form.] 
educational/cultural uses of films and musical works in the home or classroom context. Clearly, the limitation on libraries' rights to lend cuts deeply into the educational and cultural prerogatives of the libraries, namely the free and reasonable dissemination of knowledge and literary and cultural works. ${ }^{209}$ Moreover, beyond restricting citizens' longstanding rights to fair, uncompensated use of copyrighted works via the libraries, the Article arguably infringes on legitimate, constitutionally-protected rights to access information, especially of those who are unable to travel or visit libraries.

Article 1275 echoes the restrictive and outdated spirit of Article 1274. This Article grants libraries the right to reproduce one copy of a copyrighted work without compensation for purposes of archiving the given work. Like Article 1274, Article 1275 Section 2 contains a broad limitation prohibiting the reproduction or storage of reproduced works via electronic means. ${ }^{210}$ In other words, libraries may reproduce works via facsimile with the aid of any technical devices, so long as the devices do not yield electronic copies of the works.

To put it mildly, the "one analog copy" rule is a relic of an analog past. ${ }^{211}$ Moreover, this rule, far from enabling a vibrant multimedia academic atmosphere, stifles research by reducing legitimate fair electronic uses to paper reproductions. ${ }^{212}$ The practical effect of Articles

209. See Janice T. Pilch, Fair Use and Beyond: The Status of Copyright Limitations and Exceptions in the Commonwealth of Independent States, 65(6) COLL. RES. LIBR. 468, $468-504$ (Nov. 2004) (discussing the evolution of fair use in Russia between the 1995 and 2004 legislation).

210. Seе Статья 1275 (Свободное использование произведения путем репродуцирования) [Grazhdanskii Kodeks Rossiiskoi Federatsii [GKRF] [Civil Code] art. 1275 (Russ.). Free use of works using reproduction].

[...]

2. Под репродушированием (репрографическим воспроизведением) понимается факсимильное воспроизведение произведения с помощью любых технических средств, осуществляемое не в целях издания. Репродуцирование не включает воспроизведение произведения или хранение его копий в электронной (в том числе в цифровой), оптической или иной машиночитаемой форме, кроме случаев создания с помощью технических средств временных копий, предназначенных для осуществления репродуцирования.

[2. Reproduction (reprographic reproduction) is understood to mean fascimile reproduction of a given work with the help of any technical device, aside from the initial production. Reproduction does not include reproduction or storage of copies in electronic (including digital), optical or other machine form, except in instances of creation with the aid of technical devices of temporary copies, for the purpose of reproduction.]

211. Pnina Shachaf and Ellen Rubenstein, A Comparative Analysis of Libraries' Approaches to Copyright: Israel Russia, and the U.S., 33:1 J. ACAD. LIBRARIANSHIP 94 (2006).

212. For instance, Article 1275, Section 1, Subsection 2, provides that reproductions of excerpts of copyrighted works may be made upon request from private citizens, but also for educational/scientific uses. Grazhdanskii Kodeks Rossiiskoi Federatsii [GKRF] [Civil Code] art. 1274 (Russ.). This is a 
1274 and 1275 read together is extremely restrictive. For example, schools are permitted to reproduce paper excerpts of given texts, but may not distribute identical excerpts in electronic form to students.

Article 1276 codifies a limited "public domain exemption." "213 Pursuant to this provision, if an architectural or artistic object is in the public domain, reproductions may be made of it and distributed via airwaves or via electronic means. As with the foregoing limited copyright exemptions, the scope of this exemption in the Internet context remains unclear. Nevertheless, this provision offers substantive justification for an expanded conception of free licensed use on the Internet. Thus, photographs of copyrighted works which are found in public squares may be broadcast on the Internet. However, it is unclear whether reproductions of copyrighted works appearing in publicly accessible museums would fall within this exemption. As will be analyzed below, this positive provision should be interpreted to allow distribution of works in all public (i.e., public squares) and quasi-public (i.e., museums) domains via electronic means such as the Internet.

\section{Russian Legal Licenses v. U.S. "Fair Use" \& Berne Convention}

As shown above, the New Copyright Law seeks to bring Russian law in line with strict international copyright norms. Consistent with the Berne three-part test, the New Copyright Law provides only the most limited legal licenses or so called "fair use" exemptions to copyright. The following section will compare the legal licenses afforded by Russian law with the right to "fair use" embodied in U.S. copyright law.

The "fair use" exemption to the U.S. Copyright Act is codified in 17 U.S.C. $\S 107 .^{214}$ Section 107 also sets out four factors to be considered in determining whether or not a particular use is fair:

subtle but drastic departure from the existing law which contains language seemingly allowing entire works to be reproduced for educational use.

213. Статья 1276. Свободное использование произведения, постоянно находящегося в месте, открытом для свободного посешения. [Grazhdanskii Kodeks Rossiiskoi Federatsii [GKRF] [Civil Code] art. 1276 (Russ.) (uncompensated use of likeness of work located in a public place)].

214. "[T]he fair use of a copyrighted work, including such use by reproduction in copies or phonorecords or by any other means specified by that section, for purposes such as criticism, comment, news reporting, teaching (including multiple copies for classroom use), scholarship, or research, is not an infringement of copyright." 17 U.S.C. $\$ 107$ (2006). The U.S. Berne Convention Implementation Act of 1988, an amendment to the Copyright Act of 1976, modified several aspects of U.S. copyright law to harmonize with the requirements of the Berne Convention (Paris Act, 1971) and entered into force on March 1, 1989. The Berne Implementation Act granted limited moral rights to authors of visual works within complex limits, but did not modify the "fair use" regime. 
(1) the purpose and character of the use, including whether such use is of commercial nature or is for nonprofit educational purposes;

(2) the nature of the copyrighted work;

(3) amount and substantiality of the portion used in relation to the copyrighted work as a whole; and

(4) the effect of the use upon the potential market for or value of the copyrighted work. ${ }^{215}$

All four of these factors require a court to look at the specific work at issue using a fact-based analysis of the copying in light of surrounding circumstances to determine whether infringement has occurred. ${ }^{216}$ As the U.S. Supreme Court has stated in one of its most recent copyright decisions:

[T] he "fair use" defense allows the public to use not only facts and ideas contained in a copyrighted work, but also expression itself in certain circumstances. ... The fair use defense affords considerable "latitude for scholarship and comment." 217

The scope of this "considerable latitude" is varied in U.S. Supreme Court jurisprudence. Nevertheless, the ambiguity in the scope allows for a wide range of ostensibly permissible uses, with only the risk of post facto sanctions for copyright infringement. In other words, rather than providing a strict positive enactment of permissible uses, the U.S. copyright law establishes a flexible retroactive "fair use" limitation. ${ }^{218}$ In over 150 years of common law litigation (prior to codification in 1976), ${ }^{219}$ this system has proven flexible, yet procedurally and substantively fair, by forcing plaintiffs to guard and enforce their rights. ${ }^{220}$

215. 17 U.S.C. $\$ 107(2006)$.

216. Campbell v. Acuff-Rose Music, Inc., 510 U.S. 569, 577-78 (1994) (stating that "[fair use in copyright] is not to be simplified with bright-line rules," but rather in "case-by-case analysis" in which the four factors "are to be explored, and the results weighed together, in light of the purposes of copyright"); see also William F. PATRY, The FAIR USE PrIVILEGE IN COPYRIGHT LAW 361-458 (1985).

217. Eldred v. Ashcroft, 537 U.S. 186, 219-20 (2003) (emphasis added).

218. See generally Daniel J. Gervais, Towards A New Core International Copyright Norm: The Reverse Three-Step Test, 9 MARQ. INTELL. PROP. L. REV. 1 (2005).

219. The U.S. Copyright Act of 1976 was a comprehensive revision of the 1909 Copyright Act. It became effective on January $1,1978$.

220. Cf. David Nimmer, "Fairest of them All" and Other Fairy Tales of Fair Use, 66 LAW \& CONTEMP. PROBS. 263 (2003) (describing inconsistency in applying the "fair use" standard). 
There are a number of practical consequences of this "reverse" approach. First, it gives private individuals and educational or cultural institutions the right to independently assess their own conduct and develop unique policies for non-infringement, based on their own capacities for risk, litigation, etc. Thus, educational bodies such as universities may interpret the first factor in the "fair use" test-whether the use is for a commercial purpose or a non-profit educational purposerather broadly (perhaps as a dispositive factor), and opt to provide clearly copyrighted material to their students under the guise of "fair use."221

The Russian legal licenses provided in the New Copyright Law correspond to the "fair use" standard found in U.S. copyright law. Major categories of historically protected use are respected in the New Russian Law. Thus, the major academic rights are adequately protected: the right to use excerpts of works in an academic setting; the right to create an archival reproduction of copyrighted works; the right to reproduce works for "personal use." In the traditional print and durable media context, these major rights are uncontroversial.

Nevertheless, with respect to emerging technologies, the positive limited legal license approach seems unworkable on its face. For instance, one can imagine myriad legitimate educational uses of copyrighted musical or film works in the home or classroom settings. Accordingly, many U.S. libraries with flexible interpretations of the "fair use" standard allow their borrowers to rent copyrighted musical works, videos, DVDs, and other media in furtherance of their educational and cultural missions. Of course, other U.S. libraries do not have faith in the purely educational motives of their patrons and restrict borrowing of these materials out of fear that the materials are being illegally reproduced. ${ }^{222}$ The important point, however, is that these libraries have an independent right to interpret their patrons' habits and devise policies which they feel adequately embody true "fair use." In other words, there is a freedom to make new technologies available, but the freedom imposes on libraries, and their borrowers, the responsibility to use the technologies in a responsible, copyright-friendly manner. Depending on their preference for risking copyright infringement lawsuits, libraries can adapt to completely new technologies (providing copyrighted works via electronic means to their

221. Indeed, this is the rationale employed by multiple major research universities in the United States (such as the University of Michigan) for allowing the Google Books project to scan, copy, and reproduce their entire collections.

222. I draw on my personal experiences with public, private, academic, and general use libraries in the United States and experiences with libraries in Russia. 
patrons) or opt in favor of tried and true paper book lending models. ${ }^{223}$ As a result, new technologies are used in innovative and efficient ways, contributing to broader dissemination of the original copyrighted work in question.

The new Russian model employs a completely different approach. For instance, by banning libraries from reproducing works in electronic form, Articles 1274 and 1275 reduce libraries to traditional book lending institutions. Not only are these acts unenforceable, but they unnecessarily inhibit innovation towards the development of more efficient library models. ${ }^{224}$ Likewise, the new acts seem to outlaw existing innovative technological library projects such as the Open Russian Electronic Library ${ }^{225}$ of the Russian State Library or the digitization efforts started by the Russian State Library in 1999 (ADAMANT project). ${ }^{226}$ Cases like ZAO Kommersant, Publishing House v. ZAO Public Library \& OOO Vector Info will likely be resolved even more forcefully against private companies wishing to establish limited public access online libraries. ${ }^{227}$

More generally, in the words of one commentator, "fair use is a much more flexible and adaptable doctrine with respect to new forms of use than

223. For instance, the Cornell University library system (along with several other American Ivy League universities) currently allows patrons to request portions of copyrighted works to be electronically imaged and sent to the borrowers via e-mail. This benefit is intended to serve Cornell scholars residing away from the main Ithaca, NY campus. The borrower of course assumes the duty to use the work in ways consistent with U.S. copyright laws.

224. LENTA News, Ostankino Court Found Lib.ru in Violation of the Rights of the Writer Gevorgyan, Mar. 31, 2005, http://lenta.ru/news/2005/03/31/lib/.

225. Откыртая русская электронная библиотека, http:/orel.rsl.ru (last visited Oct. 25, 2011) (previously containing over 8,655 online books); see also National Electronic Library, http://rusnel .ru/index.php (last visited Oct. 25, 2011) (providing free access to multiple current copyrighted literary works, e.g., ten of Boris Akunin's stories and plays). It should be noted that in its charter, the National Electronic Library requires member libraries and contributors to the electronic fund to be copyright holders or to act pursuant to the Law on Author's Rights and Neighboring Rights. See Charter of Russian Electronic Library, Section 1.1, Legal Basis, available at http://rusnel.ru/conception.htm.

226. The ADAMANT project was started in 1999 with the goal of digitizing (creating digital copies) the entire Russian State Library collection, over 40 million works. The ADAMANT project eventually evolved into the Open Russian Electronic Library and the National Electronic Library. See Creating an Information System for the Russian State. A pilot project Challenging IT, 66th IFLA Council and General Conference, http:/www.ifla.org/IV/ifla66/papers/056-142e.htm (last visited Oct. $25,2011)$.

227. V.B. Naumov, LAW AND THE INTERNet: ESSAYS ON THEORY AND PRACTICE 199-205 (University Publishing House 2002). The case involved a private for-profit company that included copyrighted material in its paid library without the copyright holders' consent. The court applied the law on libraries to the private company, holding that the company did not have a right to use the content. The holding rested on several factors: (1) the access to the website was on a subscription or paid basis; (2) the publication on the Internet differed from traditional library uses in that it was permanent. A modern case involving similar "embedded" content with a "time-bomb" (file expires after certain time) would have probably passed the court's scrutiny under the current law. However, under the New Copyright Law, this act would probably constitute infringement. 
purpose-specific exception, most of which are not technologically neutral." 228 This is not to say that the current "fair use" standard in American law is fully workable or applied consistently with respect to alleged Internet copyright violations. It is not. The only real advantage of the "fair use" standard is its relative flexibility. Scholars know that they may use works "fairly" and act "fairly" according to their own meanings of what is "fair." One student standing at a Xerox ${ }^{\circledR}$ may copy five pages of a textbook and deem it fair; another may copy five books and deem it fair. Depending on the context, both instances may be legitimate fair use. The key is that it is not necessary to draw bright lines, to impose page limits on copies, or to restrict the modes of reproduction. Some students or professors may be caught copying books and be forced to pay compensation, but most will know they have a reasonable right to copy, and more importantly, will continue to copy.

However, compared to the relatively flexible "fair use" standard, which may be litigated following particular alleged copyright violations, the legal license approach works the opposite way. It seeks to enumerate specific rights that institutions have, but by doing so ambiguously, it stifles the institutions' rights to invent and experiment with novel teaching techniques and new technologies in the classroom, such as multi-media teaching and playing films in cultural centers.

These problems are not unique to Russia. Nearly two decades of IP litigation in the United States has not produced a workable "fair use" standard with respect to the copyright obligations of Internet service providers, Internet cataloguers, Internet encyclopedias, and so forth. However, it is perhaps the failure to produce a comprehensive catalog of Internet rights and liabilities which has contributed to the dramatic growth of the information technology (IT) sector, and the Internet in particular. As renowned Internet law expert Lawrence Lessig and others have argued, it was perhaps a boon to the IT industry and to American culture that many of the most popular Internet uses remained in legal limbo, or in the gray shadow of legitimacy in the first decade of the Information Age. ${ }^{229}$ Even today, the most important issues of copyright law, including the scope of the "fair use" exemption, are being tested and reshaped by Google (e.g., Google Books) and numerous other Internet pioneers eager to stake legitimate legal claims to virgin Internet territory. ${ }^{230}$ Despite new

228. See Gervais, supra note 218 , at 27 .

229. See generally LAWRENCE LESSIG, FREE CUlTURE (2006), available at http:/www.freeculture.cc/freecontent/.

230. For instance, the right of search engines to display portions of other websites was extensively 
legislation in the United States such as the Digital Millennium Copyright Act (heightening penalties for copyright infringement on the Internet), U.S. law remains uncertain with respect to key copyright issues. Not surprisingly, as the law remains uncertain, innovation continues.

The Russian experience with Internet innovation has been equally if not more spectacular since the early 1990 s, precisely because of a similar legal uncertainty regarding the status of the Internet. For this reason, sites like AllofMP3 sprung onto the international stage, gaining wide following. Russian Internet use surged and a vibrant and lucrative information technology sector was able to develop throughout Russia and the former Soviet Union, including smaller nations like Moldova. Immediately after its launch in 2000, AllofMP3 became embroiled in domestic lawsuits by international firms, including the RIAA. The disputes continued throughout the 2000s. Despite mounting international opposition, the legal theories being litigated before the local Moscow courts pointed to a growing appreciation among Russian jurists for American-style ambivalence in Internet law. ${ }^{231}$ Uncertainty in Russian law on noncontractual licensing also seemed to encourage innovation in the sector throughout the $1990 \mathrm{~s}$ and early $2000 \mathrm{~s} .{ }^{232}$ However, as shown above, in enacting the New Copyright Law, Russia sought to greatly limit traditional legal licenses and fair use exceptions, indeed in a far more restrictive manner than found in U.S. legislation.

Similarly, along with enacting the New Copyright Law, from 2007, Russia also began an aggressive effort to implement and strictly enforce the letter of the new law. In June 2007, for instance, the popular filesharing site mentioned above, AllofMP3.ru, was shut down due to pressure from the Russian government. Not coincidentally, the lawsuit by

debated within academic circles in the early years of the Internet, with the courts ultimately ruling that search engine displays were permissible fair uses. See, e.g., Kelly v. Arriba Soft Corp., 336 F.3d 811 (9th Cir. 2003) (inlined thumbnails in search engine results considered fair use since they did not undermine the copyright holder's potential market); Perfect 10, Inc. v. Amazon.com, Inc., 508 F.3d 1146 (9th Cir. 2007) (echoing Kelly); Field v. Google, Inc., 412 F. Supp. 2d 1106 (D. Nev. 2006) (content cached by search engines' crawlers did not violate fair use principles); see also Danny Sullivan, Google Book Search Wins Victory in German Challenge, SEARCh ENGINE WATCH, June 28, 2006, http://searchenginewatch.com/article/2058383/Google-Book-Search-Wins-Victory-In-GermanChallenge (noting that a German court advised against plaintiff's lawsuit against Google Book Search based on the theory that Google's display of portions of copyrighted work in Google Book Search engine was similar to search engines' display of result data).

231. On August 27, 2007, a Moscow district court ruled that AllofMP3.com operated within the law, http://www.allofmp3.ru/press.shtml (last visited Oct. 25, 2011).

232. Budylin \& Osipova, supra note 176 , at 1. 
the RIAA was dropped shortly thereafter. ${ }^{233}$ Since 2008 , the New Copyright Law has also signaled the start of a new era in Russian Internet law, more broadly speaking, marked by increasingly detailed positive laws relating to property rights in non-traditional network media, Internet, and over products of intellectual activity concerning the Internet. Aside from an expected decrease in experimentation and innovation by information technology firms due to exposure to litigation risk, this new era is also marked by greater cooperation between Russia and Western firms in defense of these rights.

The forecast for the immediate future of copyright in Russian Internet law seems filled with challenges. With the enactment of the New Copyright Law, Russia seems poised to take on an ambitious range of enforcement measures aimed at "cleaning up" its Internet piracy problem, as well as its image with respect to copyright enforcement before the international community. The end result promises to be harmonization between Russian, EU, and broader international copyright law, all aimed at supporting Russia's accession to the WTO. ${ }^{234}$

The more important question at this point is whether Russia will need to further amend its New Copyright Law to conform to WTO standards? At present, it is doubtful that further law reform will be necessary, as the current law seems to codify the existing Berne three-step test ${ }^{235}$ and is likely to be strictly applied in practice. ${ }^{236}$ Thus far, the scope of this threepart test has not been delimited on the international plane, and application of the test has produced only general guidelines. ${ }^{237}$ Furthermore, Russia

233. Music Industry Drops Copyright Suit Against Russian Music Site, ALLFMP3 BLoGs (May 26, 2008, 12:35 PM), http://blogs.allofmp3.ru/music_news/2008/05/26/music-industry-drops-copyrightsuit-against-russian-music-site/.

234. Cameron, supra note 190.

235. The Berne three-step test is a clause that has been included in several international treaties on copyright (notably the TRIPS Agreement, the WIPO Copyright Treaty, the EU Copyright Directive, and the WIPO Performances and Phonograms Treaty). It imposes constraints on the possible limitations and exceptions to exclusive rights under national copyright laws. The most important version of the test is that included in Article 13 of TRIPS. It reads: "Members shall confine limitations and exceptions to exclusive rights to [1] certain special cases which; [2] do not conflict with a normal exploitation of the work; and [3] do not unreasonably prejudice the legitimate interests of the rights holder." TRIPS Agreement, supra note 175, art. 13.

236. Research has not produced a sufficient number of Russian cases interpreting the New Copyright Law. Therefore, the analysis regarding likely application in practice is based on firsthand empirical research and discussions with Russian IP attorneys and scholars.

237. See Gervais, supra note 218, at 14-19 (analyzing application of three-part test to US Copyright Act by 2001 WTO panel). 
has recently acceded to the World Intellectual Property Organization ("WIPO") Internet Treaties. ${ }^{238}$

One can expect that in the near term Russia will seek to further restrict fair use exemptions, particularly in the Internet context. To promote enforcement, Russia may even experiment with new anti-piracy measures such as Internet trolls, restrictive firewalls, and similar measures currently used and being developed by governments like China to restrict Internet access. With a large, highly sophisticated pool of information technology specialists, Russia is particularly well-equipped to experiment with disastrous Internet monitoring measures under the guise of copyright enforcement. The threat of such measures for media and particularly Internet freedom in Russia cannot be understated, especially in light of Russia's historical experience with state censorship and restrictions on the flow of information.

In sum, the New Copyright Law accomplishes exactly what its writers set out to do-it marks a complete break with the legacy of Soviet copyright policy that remained in the 1993 Law on Author's Rights (such as the broad academic/cultural use exemption) and harmonizes Russian law with existing international copyright norms. As has been argued elsewhere, ${ }^{239}$ instead of developing workable parameters for copyright exceptions for the Internet, or invoking new technologies that mitigate the threats against copyrights, or drawing a flexible line between copyrights and exceptions, ${ }^{240}$ the New Copyright Law can have the unintended consequence of chilling the exercise of free speech. As a result of the strict New Copyright Law and out of fear of litigation, companies, organizations, and individuals may be less likely to exercise their constitutionally protected speech and access to information rights not only in the Internet context, but also more generally. Subsequent waves of IP law reform in Russia will most likely attempt to delineate these previously ambiguous rights.

238. The WIPO Internet Treaties refers to the WIPO Copyright Treaty (WCT) and the WIPO Performances and Phonograms Treaty (WPPT). The WCT and the WPPT entered into force on March 6, 2002, and May 20, 2002, respectively. See World Intellectual Property Organization, WIPO INTERNET TREATIES, available at $\mathrm{http}$ //www.wipo.int/freepublications/en/ecommerce/450/wipo_pub_ 1450 in.pdf.

239. Conference Presentation at Moscow State University, Faculty of Journalism: "Fair Use" In Russia's New Internet Regulation Regime-A Law and Economics Perspective, Mass Information in Internet: Freedom and Responsibility (Oct. 12-13, 2007).

240. For instance, Digital Rights Management, or legal recognition of viable read-only alternatives to text versions of e-books (i.e., non-printable, non-copyable Adobe .pdf files-such as Антон Серго, ИНТЕРНЕТ И ПРАВО (2002), available at http://internet-law.ru/book/text/book_5.pdf). 
But as concerns us here, the domestic IP sector reforms are also symptomatic of several broader developments in Russian international legal theory. First, just as in the Interwar period, the post-Soviet reforms signify a general willingness to conform to customary and evolving international norms. From the standpoint of Russian international lawyers, the domestic implementation of international norms aimed at delineating and defending private property rights seems to constitute a core function of public international law. As in the Interwar period, post-Soviet international jurists are fully aware that state relations are no longer confined to matters of war and peace, but increasingly encompass commercial concerns. In Russia, economic practices and firm activity are perceived as having an impact on Russia's image as a responsible economic actor. The image of a predictable economic actor is also bolstered by actions which demonstrate predictable state action, and vice versa. This means that, for now, Russia will continue its efforts to strengthen its IP regime, especially in high-profile copyright infringement cases.

\section{Policy Trade-Offs, Resistance, Values, and Interests}

The historical outline provided above suggests several normative lessons. First, and most significant, the WTO's continued opposition to Russia's accession has had the effect of forcing Russia to explore alternative economic integration arrangements, often along lines resembling the previous Soviet economic union. ${ }^{241}$ Russia's surprise announcement in July 2009 that it intended to accede to the WTO as a regional customs body along with Kazakhstan and Belarus (instead of as a state party) sent ripples of discontent in the international trade community. However, this resistance was to be expected. Russian international law discourse has been voicing discontent regarding the WTO accession process for at least the last five years. ${ }^{242}$ Leading Russian jurists involved

241. Hiroshi OdA, RusSiAn COMMERCiAL LAW (2d rev. ed., Nijhoff 2007).

242. Г.М. ВЕЛЬЯМИНОВ, МЕЖДУНАРОДНОЕ ЭКОНОМИЧЕСКОЕ ПРАВО И ПРОЦЕСС $§ 588$ (Волтерс Клувер, 2004) ("Соответствующий договорно скрепленный синдром безответственности питает отчасти, наряду $\mathrm{c}$ прочими мотивами, и американское сопротивление формально давно назревшему приему России в ВТО, ибо в рамках этой организации придется отказаться от дискриминационной безответственности перед Россией.") [G.M. Velyaminov, International ECONOMic LAW And Procedure $\$ 588$ (WaltersKluwer, 2004) ("The corresponding and contractually binding syndrome of irresponsibility [regarding the U.S.Russian bilateral agreement absolving U.S. firms of liability in Russia] partially feeds into, along with other motives, the American opposition to Russia's accession to the WTO, which is formally long overdue. As a result, Russia will likely be forced to withdraw from the discriminatory treatment [of the 
in the IP harmonization efforts, like Victor A. Dozortsev, genuinely hoped that their efforts would be rewarded with WTO accession and were surprised, if not outright offended, ${ }^{243}$ when the United States continued to stall Russia's integration efforts. ${ }^{244}$ For its part, the American lobby has raised legitimate concerns regarding the implementation of the New Copyright Law and related legislative enactments. Yet there is a palpable indignation among certain Russian jurists at the treatment Russian goodfaith efforts have received in the U.S. For instance, American demands that copyright violations be governed by criminal, rather than civil law, and that software programs carry copyright protection rather than patent protection, were extensively debated in the Russian working group, but ultimately rejected on policy grounds, such as the fact that no Western European state afforded such protections. ${ }^{245}$

WTO].")]. Velyaminov, a professor of law and a chief researcher at the ISL, is one of Russia's leading experts on international economic and trade law.

243. Александр Л. Маковский, Американская История, 7(1) ВЕСТНИК ГРАЖДАНСКОГО ПPABA 165-96 (2007) [Alexander L. Makovsky, American History, 7(1) VESTNIK GRAZHDANSKOGO PRAVA 165-96 (2007)] (discussing the involvement of individual U.S. Senators during the development of Part IV, and personal dissatisfaction with their conduct); see Letter from Chuck E. Grassley \& Max Baucus, U.S. Senators, to Peter F. Allgeier, Acting United States Trade Representative (Apr. 11, 2005) (on file with author), reproduced at http://finance.senate.gov/ newsroom/ranking/release/?id=ef7 1 e567-f685-4b37-9203-2d56fca0e86a (letter concerning U.S. reservations about Russia's accession to WTO due to IP infringement). Alexander L. Makovsky (b. 1930 ) is one of the leading civil law jurists in Russia and a renowned authority on intellectual property law. He was the deputy chair of the working group that developed Part IV. See also АЛЕКСАНДР Л. МАКОВСКИЙ, О КОДИФИКАЦИИ ГРАЖДАНСКОГО ПРАВА (1922-2006) (М: СтатуТ, 2009) [Alexander L. Makovsky, On the Codification of Civil Law (1922-2006) (Moscow: Statute 2009)]; А.Л. Маковский, Обращение к читателю, ВЕСТНИК ГРАЖДАНСКОГО ПРАВА ("Создание нового российского гражданского законодательства еще не завершено. Далеко не все в уже принятых и действующих законах себя оправдало-это и многие «американизмы» в корпоративном праве и нормативных актах от инвестиционных ценных бумагах, и крайне противоречивое законодательство о некоммерческих организациях, и многое другое. Ряд крупных законов нуждается в продуманном совершенствовании. Не является в этом отношении исключением и Гражданский кодекс.") [Alexander L. Makovsky, Appeal to the Reader, VESTNIK GRAZHDANSKOGO PRAVA, available at http:/www.mvgp.ru/full_obr/ ("The creation of a new Russian civil code is not yet complete. By far not all of the adopted and active laws were vindicated [by history]—along with a number of "Americanisms" in corporate law and normative acts on investments and negotiable instruments, and contradictory legislation on NGOs, and much else. A series of major laws is in need of measured reevaluation, not excluding the civil code.")].

244. See generally ВИКТОР А. ДОЗОРЦЕВ, ИНТЕЛЛЕКТУАЛЬНЫЕ ПРАВА: ПОНЯТИЕ, СИСТЕМА, ЗАДАЧИ КОДИФИКАЦИИ (СБОРНИК СТАТЕЙ) (М.: СТаTУT, 2005) [VICTOR A. DOZORTSEV, Intellectual Property: Conception, System and Problems of Codification (Collected ARTICLES) (Moscow: Statute 2005)]. Dozortsev (1928-2003) was one of the leading Russian jurists in the working group developing Part IV of the Civil Code.

245. Pleshanova, supra note 186 . U.S. copyright law also provides mainly civil remedies, though the U.S. government may file criminal charges for any violation of the Copyright Act provided that such infringement is undertaken "willfully" and "for purposes of commercial advantage or private financial gain." 17 U.S.C. $\$ 506$ (a) (2006). However, the United States has moved more aggressively 
Second, U.S. insistence on further law reform-even after the passage of Part IV of the Civil Code-seems unlikely to resonate due to the U.S.'s failure to deliver on its promises (most significantly, dropping opposition to WTO accession). For instance, in its 2009 "Section 301 " report, the Office of the U.S. Trade Representative "look[ed] to Russia to make further progress by ensuring that the Russian Customs Code, Civil Code and Law on Medicines comply with the Intellectual Property Rights ('IPR') Bilateral Agreement and the relevant TRIPS Agreement obligations that will take effect upon Russia's accession to the WTO."246 While these recommendations are certainly warranted, they are increasingly perceived by Russian elites as disingenuous.

In contrast to the United States, the EU has been consistently in favor of Russian accession, notwithstanding Russia's evolving IP regime. ${ }^{247}$ This may be reflected in the EU's own complex process of standardization in the realm of IP throughout the $1990 \mathrm{~s}^{248}$ The underlying rationale behind EU standardization in the IP domain is similar to any harmonization project.

The underlying philosophy of standardization, to put ideas into the public domain, and the philosophy of intellectual property rights, to maintain ideas or expression as private properties, are inconsistent and that tensions between them could inhibit the rapid adoption of EU standards. ${ }^{249}$

However, the EU proceeded with the understanding that actual de facto harmonization could only occur as the result of actual trade, contestation, and revision over a prolonged period of time following WTO accession. ${ }^{250}$

towards criminalizing copyright infringement, particularly to fight piracy over the Internet. See, e.g., No Electronic Theft (NET) Act, Pub. L. No. 105-147, 111 Stat. 2678 (1997).

246. Office of the U.S. Trade Representative, Special 301 Report 16 (2009), available at http://www.ustr.gov/sites/default/files/Full\%20Version\%200f\%20the \%202009\%20SPECIAL \%20301 $\% 20 R E P O R T$.pdf.

247. For EU-Russia trade issues related to Russia's accession to the WTO, see Rafael Leal-Arcas, The European Union and New Leading Powers: Towards Partnership in Strategic Trade Policy Areas, 32 FordHAM INT'L L.J. 345 (2006); Despite Obstacles, EU Expects Russia to Join WTO This Year, 12 Int'l Centre for Trade \& Sustainable Dev: News \& Analysis 23 (2008), available at http:// ictsd.org/i/news/bridgeweekly/12267/.

248. Michael A. Epstein, Ronald S. Laurie \& Lawrence E. Elder, International Intellectual Property - THE European Community and EASTERn Europe $\uparrow 12.5$ (Prentice Hall Law \& Business 1992).

249. Id. (citing European Commission, Communication on the Development of European Standardization -Action for Faster Technological Integration in Europe, COM (90) 456 final, 1991 (C 20) 1 [Green Paper], at 25).

250. See Backer, supra note 159 , at 3-17 (suggesting that harmonization and convergence is primarily the result of, and in furtherance of, economic activity). 
The EU's position on Russian intellectual property reform is informed by this pragmatic experience, and is borne out by the harmonization reforms in former socialist countries that have since joined the EU. The principal lesson of EU harmonization in the IP domain was that even as states adopt formal European Community directives, emerging technologies will continue to challenge traditional IP forms. ${ }^{251}$

Third, while there is a dissenting isolationist strain in Russian foreign policy discourse, ${ }^{252}$ Russian leaders and elites are fully committed to the view that globalization is a good thing, and that further integration into the global trading regime is in Russia's long term interests. This thinking has been entirely consistent with the historical development of international law in the West ${ }^{253}$ and in Russia since the collapse of communism. The notion that individuals and firms have universal fundamental economic rights that transcend the wills of national rulers has strong resonance in contemporary Russia. As seen above, even during the early and later Soviet periods, the USSR subordinated its ideological rhetoric to more concrete economic realities. At the same time, Russian leaders are noticeably sensitive to what they perceive as American international trade gamesmanship, egoism, ${ }^{254}$ and imposition. ${ }^{255}$ Under Putin, Russia has closed nearly all outstanding international aid projects and reform initiatives. $^{256}$ Furthermore, Russia has also started to reassess its reliance

251. See Peter Smulders, The European Union and Copyright $\$ 4(2)$, in INTERNATIONAL COPYRight LAW AND PRACTiCE (Paul Edward Geller ed., 2009).

252. Вадим Цымбурский, Остров Россия, РусскиЙ АРХИПЕЛАГ (2002) [Vadim Tsimburgskii, The Island of Russia, RUSSIAN ARCHIPELAGO (2002)], available at http:/archipelag.ru/ru_mir/ostrovrus/cymbur/island_russia/.

253. Betn Steil, ManUel hinds, Money, Markets \& Sovereignty 11 (2009).

254. Bureau Report, US Can Never Regain Its Status in Global Market: Putin, ZeENews, Oct. 9 , 2008, (on file with author); see also VINCENT BARNETT, A HISTORY OF RUSSIAN ECONOMIC THOUGHT ix (Routledge 2005) (explaining Western economists' view of Russian counterparts as "inferior").

255. Katherine Verdery, What Was SOClaLism, AND What COMES NEXT? 3-16 (1996) (discussing the perception of the transferring of Western institutions, such as markets and democracy, to non-Western settings).

256. World Bank Project No. P008831 (Russian Legal Reform Project) (June 13, 1996 to December 31,2005 ), http://web.worldbank.org/external/projects/main?pagePK $=64283627 \& \mathrm{piPK}=$ 73230\&theSitePK=40941\&menuPK=228424\&contentFed=yes\&Projectid=P008831; see also World Bank Report No. T-6883-RU, Appendix G (setting forth priority substantive areas of law such as international trade and property law). The project was administered by the Russian Foundation for Legal Reform ("RFLR"), a governmental non-profit organization founded in April 1996 pursuant to Presidential Decree No.81 of February 2, 1996. The founders were the Administration of the President of Russian Federation, the Ministry of Finance, the Ministry of Justice, the Federal Commission on Securities and Stock Market of RF Federal Government, and the Russian Academy of Science. The EU also participated in Russian law reform from December 1997 to March 2001. See, e.g., Strengthening the State of Law and Legal Education Under New Market Relations, Tacis Project EDRUS 9607. Smaller mainly European-funded law reform research projects continued in Russia 
on Western economic models in the wake of the financial crisis, although what tangible changes will result remains to be seen. ${ }^{257}$

\section{CONCLUSION}

Despite ascribing to a communist ideology and professing an exceptional "socialist international law" in the domain of international intellectual property law (specifically, copyright law), the Soviet Union has consistently worked to harmonize its domestic law with general developments in international law. This has been done to facilitate trade in material and intellectual property with Western powers. Soviet international law scholars reconciled legal harmonization with communist principles by employing a number of novel rhetorical and argumentative structures, such as: (1) the transition theory to justify temporary concessions and compromises; (2) international legal instrumentalism to justify the ends over the means; and (3) de-politicization of substantive international law matters to make intellectual property protection a matter of administrative international law, and hence not subject to theoretical contestation with the West.

Since the collapse of the USSR, Russia has implemented at least four major law reform projects in the IP domain $(1993,1994,2004,2008)$ to further harmonize domestic law with emerging international norms. The latest round of reforms is intended to be a definitive domestic codification of Russia's outstanding international obligations in the realm of intellectual property. In anticipation of, and in furtherance of, WTO accession, Russia has harmonized its domestic legislation with all outstanding TRIPS obligations, including the WIPO Internet Treaties. Comparative analysis of Russian copyright law with U.S. "fair use" standards reveals Russian copyright law to be at least as stringent as its U.S. counterpart.

The WTO's continued refusal to permit Russian accession is based, in part, on Russia's lax enforcement of IP protections. Considering that Russia has coordinated its formal domestic legislation with international

through 2008, such as that administered by the Dutch Center for International Legal Cooperation. See DUTCH CENTER FOR INTERNATIONAL LEGAL COOPERATION, ANNUAL REPORT 18 (2007), available at http:/www.cilc.nl/annualreport2007.pdf (three-year Matra-funded project to assist the harmonization of Russian civil and administrative procedure law ended in July 2008).

257. Robert Jellinek, Russia and the Global Meltdown: Domestic and Foreign Policy Responses to the International Financial Crisis 33, CARNEGIE CENTER, available at http:/carnegieendowment .org/files/1 1972Jellinek.pdf. Jellinek's analysis of Russia's response offers an excellent introduction to Russia's measures in the wake of the crisis. 
592 WASHINGTON UNIVERSITY GLOBAL STUDIES LAW REVIEW [VOL. 10:535

norms, it is unclear how long Russia must wait to demonstrate acceptable levels of enforcement. This ambiguous position has generated resentment among leading Russian policy-makers and jurists. This is likely to hinder future reform projects, spawn further resistance to WTO-mandated reforms, and interrupt the organic legal harmonization efforts underway in Russia. 